DR. DAVID MILLWARD (Orcid ID : 0000-0001-5234-4735)

Article type : Original Manuscript

\title{
Early Mississippian evaporites of coastal tropical wetlands
}

DAVID MILLWARD*, SARAH J. DAVIES†, FIONA WILLIAMSON

TIMOTHY I. KEARSEY*, CARYS E. BENNETT†, JOHN E. A. MARSHALL $\ddagger$ and MICHAEL A.

E. BROWNE*

*British Geological Survey, The Lyell Centre, Edinburgh EH14 4AP, UK (E-mail: dmill@bgs.ac.uk) † School of Geography, Geology and the Environment, University of Leicester, Leicester LE1 7RH,

$U K$

¥Ocean and Earth Sciences, University of Southampton, National Oceanography Centre, European Way, Southampton SO14 3ZH, UK

Associate Editor - Jim Hendry

Short Title - Coastal wetland evaporites

\begin{abstract}
Extensive evaporites in Lower Mississippian successions from palaeoequatorial regions are commonly used as evidence for an arid to semi-arid palaeoclimate. However, in this study, detailed studies of evaporites and their context refute this interpretation. Detailed sedimentological and petrographical analysis of the Lower Mississippian of northern Britain, is combined with archived log

This is an Accepted Article that has been peer-reviewed and approved for publication in the Sedimentology, but has yet to undergo copy-editing and proof correction. Please cite this article as an "Accepted Article"; doi: 10.1111/sed.12465 This article is protected by copyright. All rights reserved
\end{abstract}


data from more than 40 boreholes across southern Scotland, northern England and Northern Ireland, and published literature from Canada. Two key cores from the Tweed Basin and the northern margin of the Northumberland - Solway Basin contain 178 evaporite intervals and reveal twelve distinct forms of gypsum and anhydrite across seven facies that are associated with planar laminated siltstone and intercalated thin beds of ferroan dolostone. Nodular gypsum and anhydrite, typically in intervals less than 1 to $2 \mathrm{~m}$ thick, are integral components of the succession. Nodular evaporite occurs within about $1 \mathrm{~m}$ of a palaeosurface, but most evaporite deposits represent ephemeral brine pans to semi-permanent hypersaline lakes or salinas on a floodplain that was subjected periodically to storm surges introducing marine waters. Formation of evaporites under a strongly seasonal climate in a coastal wetland is supported by palaeosol types and geochemical proxies, and from palaeobotanical evidence published previously. Although $65 \%$ of modern equatorial areas experience a strongly seasonal climatic regime, salinas and sabkhas are a minor component today in comparison with the evidence from these Lower Mississippian successions. This implies that the earliest terrestrial environments were complex and dynamic providing a diverse range of habitats in which the early tetrapods became terrestrialized and represent a setting that is rarely preserved in the geological record.

Keywords Evaporite rock, monsoon, palaeoenvironment, tetrapod, Tournaisian.

\section{INTRODUCTION}

Two contrasting models for the early Mississippian climatic regime of southern Laurussia are presented in the literature: a humid climate (e.g. van der Zwan et al., 1985) with seasonality (e.g. Falcon-Lang, 1999) or an arid/semi-arid climate (e.g. Scott, 1986; Wright, 1982, 1990; Bateman \& Scott, 1990; Andrews \& Nabi, 1998). Understanding the climate and palaeoenvironments at this time is important because the terrestrialization of vertebrates occurred during the Tournaisian, following

This article is protected by copyright. All rights reserved 
the end-Devonian mass extinction event (Kaiser et al., 2015). Climate and palaeoenvironment may be among the underlying factors that enabled this profound step in the evolution of life on Earth.

The early and mid Tournaisian humid climate proposed by van der Zwan et al. (1985) is supported by a number of UK-focussed studies (e.g. Hird \& Tucker, 1988; Brofiscin Oolite, South Wales). In the Tournaisian of south-east Scotland, Kearsey et al. (2016) linked the record of repeated river flood events (Bennett et al., 2016) with palaeosol data to conclude that the climate was tropical and markedly seasonal. These interpretations are consistent with the association of the reconstructed forest tree Stamnostoma huttonense with well-drained palaeosols (Retallack \& Dilcher, 1988) and the presence of growth rings in fossil wood (Falcon-Lang, 1999, 2004).

In contrast, other observations from the UK Tournaisian are cited as evidence for an arid or semi-arid climate, including the presence of calcretes in south-east Scotland (Andrews \& Nabi, 1998) and southern Britain (Wright, 1982, 1990), and the occurrence of evaporite rocks (Scott, 1986; Bateman \& Scott, 1990). Young (1867) first recorded veins of fibrous gypsum cutting Tournaisian strata north of Glasgow, but the widespread occurrence of evaporite rock in this succession was revealed finally in a suite of boreholes drilled across the region by the British Geological Survey from the late 1960s onward (e.g. Paterson \& Hall, 1986).

For the first time, the current study describes a diverse suite of evaporite rocks from the lower Mississippian Ballagan Formation of northern Britain and interpret these within their host sedimentary succession (Bennett et al., 2016, 2017; Kearsey et al., 2016) and regional context, discussing the implications for regional climate interpretations. This analysis provides an important insight into an unusual palaeoenvironment with few modern analogues. The significance of this palaeoenvironment is increased in the light of new discoveries of vertebrate fossils with terrestrial capability in the Ballagan Formation and its correlative, the Horton Bluff Formation, in Nova Scotia (Clack, 2002; Smithson et al., 2012; Anderson et al., 2015; Clack et al., 2016).

This article is protected by copyright. All rights reserved 


\section{GEOLOGICAL SETTING}

In the Tournaisian, Nova Scotia and Scotland were located in equatorial latitudes on the southern margin of Laurussia (Domeier \& Torsvik, 2014). Oblique dextral collision between Laurussia and Gondwana began in Famennian to Tournaisian times (Leeder, 1971, 1974; Leeder et al., 1989; Gawthorpe et al., 1989), and resulted in the fragmentation of part of the Laurussian margin to form a mosaic of linked sedimentary basins in the Midland Valley of Scotland and northern England (Coward, 1993). The early fill to these basins includes the Ballagan Formation (Figs 1 and 2), underlain by the Kinnesswood Formation and in the west overlain by the Clyde Sandstone Formation. The last two comprise similar facies. They consist of fluvial, cross-bedded sandstone in upward-fining cycles, interbedded with red and purple mudstone, multiple intervals with carbonate nodules and thin beds of concretionary limestone ('cornstones'; Read \& Johnson, 1967; Eyles et al., 1949; Francis et al., 1970; Leeder, 1976; Leeder \& Bridges, 1978; Young \& Caldwell, 2011, 2012). The 'cornstones' are palaeosols containing extensive pedogenic carbonate and indicate a semi-arid or arid environment (Burgess, 1961; Leeder, 1976; Andrews et al., 1991; Wright et al., 1993). In the Scottish Borders, near Berwick upon Tweed, and along the northern margin of the NorthumberlandSolway Basin, the Fell Sandstone Formation overlies the Ballagan Formation (Fig. 2).

Contrasting sharply with the units above and below, the Ballagan Formation consists dominantly of grey siltstone and thin beds of argillaceous ferroan dolostone (previously 'cementstone'), with varying proportions of sandstone, flood-deposited sandy siltstone, palaeosols and evaporite rock (Anderton, 1985; Scott, 1986; Andrews et al., 1991; Andrews \& Nabi, 1994, 1998; Bennett et al., 2016; Kearsey et al., 2016). The formation is best exposed in a $520 \mathrm{~m}$ thick, vertically dipping coastal section at Burnmouth (Fig. 1), bound by the Kinnesswood Formation at the base and Fell Sandstone Formation at the top (Fig. 2). In this section, and within the Norham West Mains Farm Borehole (see below), Bennett et al. (2016; table 1) identified ten facies and three facies associations 
within a coastal floodplain succession. The facies associations are fluvial, overbank and saline hypersaline lake. Evaporites occur mostly in the saline-hypersaline lake facies association, but are also present in the overbank facies association.

\section{MATERIALS AND METHODS}

This study combines data from the British Geological Survey (BGS) borehole record collection with detailed studies of cores from three boreholes at the National Geological Repository, BGS Keyworth. The borehole logs archive contains ca 40 records that proved significant occurrences of the Ballagan Formation (Supplementary Data 1). Descriptive logs of 12 of these boreholes (Fig. 1), made in the past by BGS staff, provide consistent information on the spatial and temporal occurrence, context and general form of the evaporite deposits, although they do not contain sufficient sedimentological detail for facies analysis.

The Norham West Mains Farm Borehole located in the Tweed Basin about $10 \mathrm{~km}$ south-west of Berwick upon Tweed, fully cored 491 m of the Ballagan Formation (Fig. 1; Supplementary Data 1; Millward et al., 2013). Cores (102 mm diameter) were sliced lengthways and recorded by sedimentary logging at a scale of 1:12.5. Evaporite intervals were described from core, core photographs, hand specimens and polished thin sections. The Hoddom No. 2 Borehole was drilled near Ecclefechan on the northern margin of the Northumberland-Solway Basin in 1994 and the $48 \mathrm{~mm}$ diameter core was logged first by A. A. McMillan (BGS). For this study, the section beneath the base of the Fell Sandstone Formation, from 104.26 to $181.74 \mathrm{~m}$ was re-logged at the scale of 1:10. A visual inspection of the Glenrothes (Fife) Borehole core provided additional information. All depths quoted in this paper are below ground level.

This article is protected by copyright. All rights reserved 
Selected thin sections were examined using an Olympus BH52 petrographic microscope (Olympus, Tokyo, Japan) and the Hitachi S-3600N (Hitachi, Tokyo, Japan) and LEO1450 VPO (Zeiss, Oberkochen, Germany) scanning electron microscopes (SEM) at the universities of Leicester and Southampton, respectively. The elements present were determined using an Oxford INCA 350 EDX (Oxford Instruments, Abingdon, UK) energy dispersive X-ray spectrometer fitted to the former SEM. Dolomite descriptions follow the scheme of Sibley \& Gregg (1987).

\section{EVAPORITE OCCURRENCE AND DISTRIBUTION}

Across the Midland Valley, evaporite rock occurrences are recorded as gypsum, along with sporadic records of siltstone pseudomorphs after halite (Figs 1 and 3). By contrast, gypsum and anhydrite are recorded from the upper and lower parts, respectively, of the Norham and Hoddom boreholes in the Tweed and Northumberland basins (Fig. 4). Scanning electron microscope analysis showed the presence of celestine, containing some barium, filling pore space and as tiny veins in dolostone associated with the evaporite rocks. In addition, Scott (1986) reported small amounts of barite from calcified nodules in dolostone beds at Burnmouth. No other evaporite species has been recorded.

These occurrences are small-scale, localized, and cannot be correlated between boreholes. Evaporite rock is absent from the succession in boreholes along northern and north-eastern flanks of the Southern Uplands. Also, it is absent where the formation thins towards the northern margin of the Midland Valley, for example on the isles of Bute and Arran (Young \& Caldwell, 2011, 2012).

The distribution of evaporite intervals is uneven through the formation (Figs 3 and 4). In the Deaconhill Borehole, for example, 12 intervals are present in the middle of the formation, whereas the 34 in the Blairmulloch Borehole are from the lower part. The 114 levels in the East Dron Borehole occur in all but the uppermost, sand-rich succession and basal Mains of Errol Member,

This article is protected by copyright. All rights reserved 
although scattered pseudomorphs after gypsum are present in the latter (Browne, 1980). In the Norham core, the 50 occurrences are throughout the succession, with 24 concentrated in the lowest $80 \mathrm{~m}$. In the Hoddom core, 128 intervals occur between depths of $131 \mathrm{~m}$ and the base of the borehole at $199 \mathrm{~m}$.

\section{Sedimentary context of the evaporite units}

Throughout the formation evaporite rock and laminated grey siltstone and dolostone are associated

(Figs 3 and 4; Bennett et al., 2016). The laminated siltstone may contain bivalves, spirorbids, ostracods, fish fragments and, more rarely, conchostracans, and may be burrowed or bioturbated. In many examples, there are no associated desiccation surfaces or other indications of emergence. By contrast, in the Glenrothes, East Dron and Norham boreholes, there are examples of desiccated horizons less than $1 \mathrm{~m}$ above layers of evaporite nodules.

Evaporite deposits occur in many beds in the Hoddom Borehole. They occur in thin and medium beds of dolostone, laminated units of siltstone, and in beds of fine-grained and very finegrained sandstone. Some siltstone and sandstone beds are bioturbated and there are scattered ostracods, plant debris, fish fragments and the bivalves Modiolus, Sanguinolites and Leiopteria (Dean, 1997). Desiccation cracks and palaeosols are few, though the tops of some dolostone beds are brecciated.

By contrast, in the Norham core, 25 evaporite units are clustered in six packages, 3.57 to $5.74 \mathrm{~m}$ thick, of laminated grey siltstone, interbedded with beds of dolostone (Supplementary Data 2); for example, the $5.74 \mathrm{~m}$ thick association contains seven evaporite units (Figs 6 and 7). Each package overlies either a rooted palaeosol, or a bed of sandy siltstone of the type described by Bennett et al. (2016). At the top, the siltstone either passes up into ripple cross-laminated, very finegrained sandstone, or is overlain sharply by fluvial, cross-bedded, fine-grained to medium-grained sandstone. Within a package, there are no clearly defined erosion surfaces, pedogenic or desiccated 
horizons. The siltstone underlying and overlying evaporite beds is burrowed and bioturbated in part, predominantly by the ichnotaxon Chondrites (Bennett et al., 2017). Although not abundant, ostracods are the ubiquitous element of a low-diversity biota that also includes fish and plant debris, and the bivalves Modiolus and Naiadites.

A thinner package, $3.14 \mathrm{~m}$ thick, includes a single nodular gypsum unit, $0.54 \mathrm{~m}$ thick, within the upper part of the succession (Fig. 8D; Facies 3 below). The base is a thin, bioturbated sandy siltstone that overlies a structureless grey siltstone with an irregular, brecciated top, interpreted as a gleyed inceptisol (Kearsey et al., 2016). The lowest $2.3 \mathrm{~m}$ comprise plane-laminated dark grey siltstone and composite dolostone units abundantly burrowed by Chondrites, ?Zoophycos and subordinate phycosiphoniform trace makers along with the presence of Naiadites (Bennett et al., 2017). The nodule bed hosted in dark dolostone containing abundant pyrite succeeds this. A unit of laminated siltstone and dolostone containing sporadic selenite crystals $18 \mathrm{~cm}$ thick overlies this bed, and the sharp base of a cross-bedded sandstone unit containing mudstone rip-up clasts and plant fragments terminates the succession.

Grey and dark grey siltstone, either as separate beds or interlaminated, hosts the evaporites. The grey siltstone is composed of normally graded laminae of angular to subangular quartz, plagioclase, potassium feldspar, muscovite and clay minerals. The dark grey siltstone also contains variable proportions of dolomite crystals, typically associated with amorphous organic matter (AOM) and framboidal pyrite. There may be patches of poikilotopic anhydrite or gypsum cement in some rocks.

Evaporites are also common in thin beds of ferroan dolostone (Fig. 3) that occur within the successions of laminated grey siltstone. Many of these evaporite-bearing dolostones are composed of planar-textured subhedral dolomite (Sibley \& Gregg, 1987) with average rhomb sizes of 40 to 
$140 \mu \mathrm{m}$. By contrast, other beds are dense, dark dolomicrite, composed of $<5 \mu \mathrm{m}$ unimodal grains of rhombohedral planar-e to planar-s dolomite. In some thin sections, spongy clotted fabrics are apparent, but SEM analysis shows the clotted fabrics to consist of the finest grained dolomite and little or no organic matter is present.

\section{DESCRIPTION OF EVAPORITE FACIES}

Table 1 summarizes the macroscopic and petrographic characteristics (Fig. 5) of 13 evaporite forms. Some forms occur singularly, whereas others associate in seven facies.

\section{Facies 1: Nodules hosted by siltstone and sandstone}

Ovoid to subspherical and irregular nodules of gypsum or anhydrite, up to $15 \mathrm{~cm}$ diameter, within thinly laminated siltstone are the most common evaporite form recorded in the Midland Valley borehole logs (Figs 3, 8A and 8B). Many occurrences in the Glenrothes and East Dron boreholes lie up to about $1 \mathrm{~m}$ beneath desiccation surfaces or brecciated top surfaces of siltstone beds (Facies 1a). In examples of this type in the Norham core, sedimentary lamination is deformed around the nodules. By contrast, evidence for emergence, including desiccation cracks and brecciated sediment, is absent from boreholes in the west of the Midland Valley and the evaporite nodules occur in thick units of planar-laminated siltstone. Similarly, in the Hoddom core packages of siltstone and finegrained sandstone, several metres thick, contain many irregularly bound, bedding-parallel layers of generally small nodules $(<2 \mathrm{~cm}$ ) (Facies $1 \mathrm{~b}$; Fig. $8 \mathrm{C}$ ). Facies $1 \mathrm{~b}$ nodules are typically concentrated becoming mosaic or chicken-wire forms and the nodule proportions may increase or decrease upwards.

This article is protected by copyright. All rights reserved 


\section{Facies 2: Nodular-laminated evaporite units}

The Norham core contains nine complex units, 0.37 to $0.80 \mathrm{~m}$ thick, of associated protonodules, nodules, chicken-wire texture and anhydrite rock. All units are in the lower part of the formation, below the depth of $320 \mathrm{~m}$. Anhydrite, commonly with porphyrotopic gypsum rims, is dominant in all but the uppermost example, which is replaced by secondary gypsum. Facies 2 does not occur in the Hoddom core or in any Midland Valley borehole. Two sub-facies are recognized (Fig. 9).

Five examples of Facies 2a (Fig. 9A) consist of a zone at the top of nodules set in dolostone, becoming chicken-wire textured downwards and passing abruptly into anhydrite rock. The matrix is siltstone within the chicken-wire and anhydrite rock zones. At the base, protonodules occur along lamination in dark grey siltstone, silty dolostone or dolostone. In two examples (421.33 to $421.70 \mathrm{~m}$; 422.14 to $422.94 \mathrm{~m}$ ), the various forms are separated by a few centimetres of laminated siltstone (Fig. 9A). A water-escape structure occurs at the top of the lower of the two examples. In the four examples of Facies $2 b$ the zones are in reverse order (Fig. 9B).

The nodular zone consists of an accumulation of round, oval or elongate anhydrite masses, typically a few centimetres in diameter, and in some examples elongated vertically. The top of a Facies $2 \mathrm{a}$ evaporite unit at 377.61 to $378.25 \mathrm{~m}$ has a sharp contact with overlying siltstone. The chicken-wire zone is 0.15 to $0.20 \mathrm{~m}$ thick consisting of small $(<5 \mathrm{~cm})$ nodules, separated by small enclaves, smears and trails of siltstone or dolostone. The nodules are irregular in shape and appear flattened horizontally.

The anhydrite rock zone is 7 to $30 \mathrm{~cm}$ thick. In Facies 2a, the base, on siltstone or laminated dolostone, is sharp and in some examples bulbous. Trails of small, irregular, angular enclaves of siltstone matrix define a crude lamination that may be parallel to that in the sedimentary rocks beneath, or steeper where the enclaves have a sigmoidal shape. In part, the contact is stylolitic and trails of the enclaves outline former nodule boundaries (Fig. 8E). Granoblastic anhydrite characterizes this unit (Fig. 5E and F).

This article is protected by copyright. All rights reserved 
The uppermost example of Facies 2a (Fig. 9C) is composed mostly of sub-horizontal bands of vertically aligned selenitic gypsum containing few anhydrite inclusions, though zones of aphanitic anhydrite are preserved locally. Common enclaves of siltstone in trails testify to the original presence of the anhydrite rock zone. Satin-spar veins disrupt gypsum nodules at the top of the dolostone bed. The very thin lamination in the dolostone is contorted.

Protonodules of either anhydrite or gypsum are present in six examples of Facies 2, in the uppermost 10 to $30 \mathrm{~cm}$ underlying the anhydrite rock zone in Facies $2 \mathrm{a}$ or at the top of the succession in Facies $2 \mathrm{~b}$. The protonodules in Facies $2 \mathrm{a}$ are 1 to $20 \mathrm{~mm}$ diameter and aligned along the lamination, which is warped over them (Fig. 9A). The smaller nodules are typically round, oval or lenticular in shape. Within siltstone or silty dolostone, dark, very thin laminae and discontinuous streaks of dolomite rhombs 1 to $5 \mu \mathrm{m}$ across, typically underlie and overlie the protonodules. In the uppermost example of Facies 2a (Fig. 9C), the protonodules are composed of gypsum with anhydrite cores and extensive dolomite replacing the sulphate minerals. Here, the protonodules are hosted by laminated dark dolostone with crystal size 1 to $5 \mu \mathrm{m}$; paler lenticular zones of planar-e to planar-s crystals 8 to $25 \mu \mathrm{m}$, define the lamination. Scattered throughout are sporadic flakes of mica and irregular, corroded quartz; anhydrite and small patches of celestine fill pores in the finer-grained dolostone.

In Facies $2 b$, the protonodules at the top of the succession are mainly irregular discontinuous streaks along the lamination and in places resemble disrupted thin layers (Fig. 9B). The proportion of evaporite decreases abruptly upwards and there also appears to be a sharp base to the laminated siltstone.

\section{Facies 3: Compact gypsum nodule beds}

Facies 3 occurs in the Norham core but not in Hoddom or elsewhere. The Norham core contains one unit, $0.54 \mathrm{~m}$ thick, with its base at a depth of $182.96 \mathrm{~m}$. It comprises two beds of closepacked, round gypsum nodules, up to $1 \mathrm{~cm}$ across, in a dolostone matrix (Fig. 8D); a few nodules are 
elongate and aligned vertically. Many millimetre-wide sub-horizontal gypsum veins cut the unit. Laminated dolomicrite, $2 \mathrm{~cm}$ thick and containing tiny clotted aggregates and wispy steaks of organic matter separates the beds. Palynological preparation shows this to include fragments of thin sheets of AOM.

The dolostone matrix is composed of unimodal, planar, 1 to $5 \mu \mathrm{m}$ dolomite crystals. Irregular, discontinuous dark laminae, up to $100 \times 6 \mu \mathrm{m}$, are rich in 5 to $35 \mu \mathrm{m}$ pyrite framboids, and clusters and trails of associated pyrite spherules up to $1 \mu \mathrm{m}$ in diameter. The very fine pyrite outlines straight and curved rods, larger oval forms and a mesh of interlinked tube-like structures entwining sporadic mica and highly corroded quartz grains, and pyrite framboids (Fig. 10E and F). The pyrite layers also locally contain randomly orientated anhydrite laths up to $10 \mu \mathrm{m}$ long, and pore and veinlike fills of celestine. Energy dispersive X-ray (EDX) spot analyses of the celestine show that it contains small amounts of Ba.

\section{Facies 4: Evaporite - dolostone/ siltstone laminites}

This facies is commonest in the Hoddom core where there are seven examples (Supplementary Data 3); descriptions of three of these illustrate the variation. Firstly, a $26 \mathrm{~cm}$ thick laminated bed of very fine-grained quartz sandstone with its base at $166.74 \mathrm{~m}$ occurs between dolostone beds containing nodular anhydrite. Evenly distributed throughout the sandstone are aggregates up to $3 \mathrm{~mm}$ across of aphanitic anhydrite; many of the aggregates resemble the equant lozenge-shaped form of gypsum (Fig. 5A). The cement is granular to poikilotopic anhydrite. Secondly, at 168.93 to $169.08 \mathrm{~m}$ laminated siltstone, very fine-grained sandstone and discontinuous layers of dolomicrite with opaque streaks are packed with lozenge-shaped aggregates up to $0.5 \mathrm{~mm}$ of aphanitic anhydrite (Fig. 5B). The shape of the anhydrite aggregates again resembles gypsum. Thirdly, a $20 \mathrm{~cm}$ thick bed with its base at $171.21 \mathrm{~m}$ is composed of laminated, very fine-grained sandstone, anhydrite rock and lenticular remnants of sandy siltstone. The anhydrite rock contains grains of quartz and feldspar with 
intricate margins and some pyrite. The sandy siltstone is composed of quartz, mica and feldspar grains, along with sporadic wood fragments, in a supporting matrix dominated by finer grained mica/illite; anhydrite heavily impregnates the sandy siltstone.

A single example of Facies 4 occurs in the Norham core at 450.50 to $451.14 \mathrm{~m}$ (Figs 6 and 7E). This consists of convolute-bedded dolostone, siltstone, claystone and laminated anhydrite rock. Interleaved with these are laminae of siltstone and anhydrite that alternate on a millimetre to submillimetre-scale (Fig. 7E). The anhydrite laminae are aphanitic with grains up to $20 \mu \mathrm{m}$ and intergrown with single crystals and irregular aggregates of planar-e dolomite with an average crystal size of $7 \mu \mathrm{m}$; thicker laminae are coarser grained and granoblastic. In the convoluted upper part of this unit, the intercalated brown claystone occurs in ragged and disrupted strips impregnated with anhydrite (Fig. 10C and D). The claystone contains thin sheets of carbonaceous matter, along with quartz and hornblende grains and randomly orientated mica plates, in a muscovite/illite groundmass containing minute pockets of anhydrite.

\section{Facies 5: dolostone-evaporite facies}

Gypsum and/or anhydrite masses commonly occur solely within ferroan dolostone beds. The proportion containing evaporite masses varies from about $5 \%$ in the Deaconhill Borehole ( 5 out of 94 ) to $16 \%$ in Loch Humphrey (20 out of 126); there are just two occurrences in Barnhill (out of 82 dolostones) and no record in the Ascog and Knocknairshill boreholes. Facies 5 is more common than Facies 1 in the Loch Humphrey borehole, but less so in East Dron. In the Glenrothes Borehole dolostone beds containing evaporite minerals have a more widespread distribution than Facies 1 (Fig. 3).

In the Norham core, 21 of 272 dolostone beds contain gypsum or anhydrite. The evaporite forms occur as sporadic disseminated crystal aggregates, void fills, irregular angular forms (Fig. 7F) or coalescent masses of round nodules. Laminated evaporite rock occurs at the base of a few beds

This article is protected by copyright. All rights reserved 
alternating with dolostone on a millimetre-scale (Fig. 7F). The host dolostone is typically a mosaic of 40 to $140 \mu \mathrm{m}$ unimodal to polymodal planar-s rhombs. Sporadic shell fragments, mainly ostracods, bioturbation and framboidal pyrite may be present. Scattered angular silt grains of quartz with highly irregular margins are present in many of the dolostone beds. A few beds display lamination, marked by layers of differing average grain size; the lamination is typically deformed around the margins of the nodules. Round patches of coarser dolomite are also present. Some of the dolostones are composed of dense dolomicrite $<5 \mu \mathrm{m}$ with opaque matter forming a spongy, clotted texture, streaky masses and discontinuous thin lenses. A water escape structure occurs at the top of one of these beds (Fig. 8F).

In the Hoddom core 62 of 117 dolostone beds contain anhydrite and/or gypsum as layers of, or dispersed, protonodules, nodules, mosaic-nodular and chicken-wire masses. Evaporite forms comprise up to as much as $75 \%$ of beds, though there are a few beds up to $15 \mathrm{~cm}$ thick of anhydrite rock containing trails of dolomicrite or siltstone. Nodules may be concentrated at the top or base of beds and the proportion both increases and decreases towards the top of many beds.

\section{Facies 6: Residue beds}

Small-scale evidence of the probable former presence of evaporite deposits is present in the upper part of the Norham core, within $50 \mathrm{~m}$ of the present-day surface. Here, two bedding-parallel zones a few centimetres thick are composed of spongy calcite networks; some of the calcite present may be pseudomorphous after gypsum. Residue beds have not been reported from any Ballagan Formation exposure.

This article is protected by copyright. All rights reserved 


\section{Facies 7: Pseudomorphs after halite}

Halite (sensu stricto) has not been recorded from the Ballagan Formation, but its former presence has been noted from euhedral pseudomorphs of siltstone or fine-grained sandstone in Chattlehope Burn (Cater et al., 1989) and near Langholm (Leeder, 1974). In addition, the logs of the Loch Humphrey, East Dron and Glenrothes boreholes (Fig. 3) record the presence of pseudomorphs up to $5 \mathrm{~mm}$, some preserving hopper faces within units of laminated grey mudstone. In the Glenrothes and East Dron boreholes, the pseudomorphs occur up to about $1 \mathrm{~m}$ beneath desiccation crack horizons or dolostone beds. This facies has not been found in the Norham or Hoddom cores.

\section{INTERPRETATION}

The mineralogy and textures of ancient evaporite rocks relate to a history of multiple replacements following deposition, burial and later exhumation (e.g. Murray, 1964; Schreiber \& El Tabakh, 2000; Warren, 2006). Despite this, the Ballagan Formation rocks contain convincing petrographic evidence that the primary evaporite mineral was gypsum. Lenticular pseudomorphs composed of aphanitic anhydrite aggregates and having the prismatic shape typical of gypsum occur in the evaporite laminites, among the small nodules, and at the margins of some larger nodules (Fig. 5A, B and D). A general diagenetic sequence from primary gypsum to anhydrite to secondary gypsum is inferred from the mineralogy and textural relationships present (Table 2). This is broadly compatible with the scheme interpreted from the Jurassic Purbeck evaporites in southern England by West (1964). Understanding the main features of the diagenetic history is important in interpreting the facies.

This article is protected by copyright. All rights reserved 


\section{Facies 1: Nodules hosted by siltstone and sandstone}

The two subfacies have distinct origins. The large nodules in Facies 1a grew by the accretion of gypsum crystals, progressively displacing host sediment from the mass and deforming the lamination (Fig. 5D). Examples of nodules in the Glenrothes and Norham cores arranged as sinuous strings fit the description of enterolithic veins (for example, Fig. 8B). Their occurrence up to $1 \mathrm{~m}$ beneath a brecciated siltstone or a desiccation crack horizon suggest that the nodules grew in the vadose or shallow phreatic zone beneath the floodplain through evaporation. This is like many Holocene supratidal sabkhas (Warren, 2006, and references therein).

The generally smaller nodule concentrations of Facies $1 b$ in the Hoddom cores cannot be related to a contemporary ground surface and the host rocks suggest uninterrupted deposition in standing water bodies. The evaporite textures exhibited are similar to those described for gypsum mush accumulations in ponds and lagoons associated with some of the Persian Gulf sabkhas (e.g. Butler et al., 1982). These nodule layers in Hoddom are interpreted as having formed during dehydration of a gypsum mush, a mechanism proposed by Warren \& Kendall (1985). The repeated beds of gypsum mush and siliciclastic sediment imply swings between episodes of desiccation and wetter conditions that provided sediment input into the water body. The evaporite nodules in boreholes from the north and west of the Midland Valley probably also formed in this way.

\section{Facies 2, 3 and 5: Association of dolostone with evaporite rock}

The strong link between evaporite rock and dolostone in the Ballagan Formation was ascribed to a floodplain saline - hypersaline facies association by Bennett et al. (2016). Dolostone beds are characteristic of Facies 2, 3 and 5, but are also a more widespread feature of the Ballagan Formation and not all contain evaporite nodules. Some of the dolostones may have a palustrine origin, similar to those for example in the Upper Cretaceous Leza Formation (Suarez-Gonzalez et al., 2015) or the upper Mississippian strata of Kentucky (Barnett et al., 2012). However, the Ballagan evaporite- 
bearing dolostones do not show the pedogenic features of those from Kentucky. The formation of gypsum in palustrine carbonates is favoured by a semi-arid climate (Platt \& Wright, 1992; AlsonsoZarza, 2003) or where dolomite dominates (Sanz-Rubio et al., 1999).

The evaporite-bearing Ballagan dolostones composed of planar-s dolomite with average rhomb sizes of 40 to $140 \mu \mathrm{m}$ are likely to be recrystallized. By contrast, the dark dolomicrites, with rhombohedral grains $<5 \mu \mathrm{m}$ are considered to be either primary precipitates, or more probably, early replacements of precursor very high magnesium calcite (Vasconcelos \& McKenzie, 1997; Warren, 2000; Gregg et al., 2015). The formation of primary dolomite has long been regarded as difficult, though Pierre et al. (1984) argued that finely crystalline dolomite is precipitated penecontemporaneously with gypsum in the Ojo de Liebre lagoon in Baja California. However, photosynthetic and chemotrophic microorganisms have been shown to have a role in dolomite nucleation, both from experimental and field studies (e.g. Vasconcelos \& McKenzie, 1997; Wright \& Wacey, 2005; Barbieri et al., 2006; Mastandrea et al., 2006; Bailey et al., 2009; Sánchez-Román et al., 2009; Bontognali et al., 2010; Bahniuk et al., 2015).

The association in modern examples of dolomite and evaporite deposits with microbial mats is well-known (for example, references above; Warren, 2010, and references therein). By contrast, in ancient deposits these organic structures are generally not preserved. However, Schieber (1999, 2007) described a range of characteristic sedimentary indicators that point to the probable former presence of microbial mats. No bioherms have been recorded from the Ballagan Formation, but of those indicators mentioned by Schieber the following are present. They are dark, crinkled, discontinuous carbonaceous laminae in dolostone and siltstone associated with evaporite protonodules; ragged ends to strips of siltstone; thin films of clay minerals with tiny pyrite aggregates draping 8 to $25 \mu \mathrm{m}$ dolomite crystals within dolostone; trails of fine pyrite in dolostone; grains of ragged quartz floating in dolostone; and randomly orientated micas within dolostone (Fig. $10 \mathrm{~A}$ to $\mathrm{F})$.

This article is protected by copyright. All rights reserved 


\section{Facies 2: Nodular - laminated evaporite units}

Superficially, Facies 2 resembles classic marine-marginal sabkha cycles of the Persian Gulf as described by Shearman $(1966,1978)$ and Kendall $(1984)$ and related by Kirkham (1997) to transgressive - regressive sea-level cycles. In this model, the identification of three main features is critical. These are laminated marine mudstone associated with microbial mats at the base commonly with gypsum crystals; displacive nodular and chicken-wire evaporites and enterolithic structures within the overlying siliciclastic or carbonate sediment; and an erosion surface at the top (Shearman, 1966, 1978; Kendall, 1984; Kirkham, 1997; Schreiber \& El Tabakh, 2000).

The thickness of examples of Facies 2 fall within the typical range of sabkha cycles of $30 \mathrm{~cm}$ to $2 \mathrm{~m}$ (Schreiber \& El Tabakh, 2000). However, the marine and intertidal deposits are substituted by planar laminated siltstone and interbedded dolostone deposited within bodies of standing water, most probably coastal plain lakes (Bennett et al., 2016). However, the presence of single tier Chondrites burrows, implying short duration occupation by marine ichnotaxa, suggests that marine water recharged these lakes during storm events (Bennett et al. 2017).

Laminated siltstone and dolostone host evaporite protonodules at the base of Facies 2a. Although the organic content of these rocks is now low, there are features strongly suggesting the growth of evaporite nodules within microbial mats. This includes the undulating form of thin layers of dark $(<5 \mu \mathrm{m})$ and light ( 8 to $25 \mu \mathrm{m})$ dolomicrite, in some cases confining the trails of protonodules, along with very thin laminae of clay minerals associated with pyrite and isolated grains of quartz or feldspar (Fig. 10A and B). The coarser Fe-bearing (EDX) dolomite crystals are compatible with growth during bacterial fermentation diagenesis as the sediment was buried (Irwin et al., 1977; Irwin, 1980; Mastandrea et al., 2006). If so, then this dolomite implies a high original organic content. Although microbial mats are an important element of the intertidal zone of marine marginal sabkhas, they also occur at the margins and on the floor of shallow lakes, among other environments (Warren, 2006, and references therein). 
Silt from runoff or from floods then buried the microbial mats. Evaporation led to the shallowing of the lake, hypersalinity and finally to deposition of dolomicrite. At this stage, the lakebed may have been the top of the dolostone, though a brecciated or cracked top to suggest subaerial exposure was not identified in any of the examples examined. A water-escape structure (Fig. 9A) is cited as evidence of exposure. Gypsum nodules then formed within the silt and dolomicrite during further evaporation and lowering of the water table. In the sabkha model this should have led to uplift and erosion (Shearman, 1978), but erosion surfaces are difficult to prove in core in the absence of a regolith which is not present in any examples from the current study.

The nodular and chicken-wire anhydrite in the Norham core are dominated by aphanitic, felted-lath and related textures which Shearman \& Fuller (1969) and Holliday (1973) considered to represent two generations of syndepositional anhydrite formation, rather than dehydration caused by burial (Murray, 1964). At the margin of some nodules, the lozenge-shaped pseudomorphs after gypsum are composed only of aphanitic anhydrite (Fig. 5D). Where these coalesce into nodules coarser, felted-laths surround the aphanitic 'cores' and, as proposed by Holliday (1973), resulted from the precipitation of anhydrite without a gypsum precursor. This interpretation implies either an increase in salinity of the enclosing brine as the temperature rises, or that the brine was at first saturated with respect to gypsum but underwent further concentration and rise in temperature to reach anhydrite saturation (Hovorka, 1992).

Progressive growth and compaction of the nodules reduced the volume of interstitial sediment from a continuous interstitial mass in the nodular zone, to discontinuous streaks and thin films in the chicken-wire zone and to trails of tiny detached enclaves defining a weak lamination in the anhydrite rock zone. The presence of trails of siltstone that define the margins of well-flattened nodules (Fig. 8E) seems to preclude the conversion of siva-twinned gypsum growths to anhydrite nodules along the lines proposed by Shearman (1985). Siltstone always hosts the anhydrite rock zone and its low permeability would impede the escape of water released by the dehydration

This article is protected by copyright. All rights reserved 
reaction, allowing extreme compaction (Shearman \& Fuller, 1969). The retention of sulphatesaturated fluid in the siltstone may have promoted anhydrite grain growth and granoblastic texture. This contrasts with the nodular and chicken-wire zones, hosted by dolostone that may have lithified early, as suggested by the 3D preservation of plant stems in some non-evaporite-bearing examples (Scott \& Meyer-Berthaud, 1985).

In Facies 2b (Fig. 9B), the sharp top to the chicken-wire zone is interpreted to be the eroded sabkha surface beneath which the evaporite rocks formed. The nodular and chicken-wire anhydrite zones are reversed only because their host is reversed. No microbial mat developed. The laminated siltstone at the top of the succession represents renewed flooding and sedimentation of silt and gypsum laminites that were disrupted during dehydration to anhydrite.

\section{Facies 3: Compact gypsum nodule beds}

The co-existence of nodular evaporite with dark dolomicrite containing abundant pyrite from the Norham core is the only example known in the Ballagan Formation. The pyritized tube-like forms (Fig. 10E and F) suggest a filamentous microbial origin. The detrital quartz and mica grains appear entwined within these structures, a feature of microbial mats demonstrated experimentally by Frantz et al. (2015). The preservation of pyrite framboids with dolomite indicates that the mineralization occurred during or shortly after sediment deposition, rather than during burial, and furthermore suggests the involvement of sulphate-reducing bacteria. Vasconcelos \& McKenzie (1997) described microbially-mediated dolomite in a layer of hypersaline black sludge just above the sediment-water interface from Lagoa Vermelha in coastal Brazil; Wright \& Wacey (2005) demonstrated this experimentally in the Coorong, Australia. The further presence of interstitial anhydrite and celestine emphasizes microbial involvement (Taberner et al., 2002; Sanz-Montero et al., 2009). The processing of organic matter by bacteria in this zone locally causes high alkalinity, a requisite for the precipitation of dolomite (Wright \& Wacey, 2005; Sánchez-Román et al., 2009). In

This article is protected by copyright. All rights reserved 
Facies 3 corroded quartz grains suggest that alkaline conditions prevailed. The relatively large size of the framboids implies that the environment was dysoxic (Wilkin et al., 1996; Bond \& Wignall, 2010).

The facies occurs near the top of a sedimentary succession that began with a flooding event and subsequently dominated by suspension sedimentation in a body of standing water. Much reduced sediment input allowed establishment of a marsh. The evaporite beds formed within the putative microbial mat before lithification, as indicated by the deformation of the mat (Fig. 10E), following further flooding and burial of the mat.

\section{Facies 4: Evaporite - siltstone/sandstone laminites}

Localized thin units (Figs 6, 7E and 8G) of alternating laminae of evaporite rock and clastic or carbonate rock represent direct sedimentation of gypsum into a brine pool; pseudomorphs after gypsum from the Hoddom core illustrated in Fig. 5A formed within the sandy substrate of the pool. The successions of alternating laminae may represent seasonal sedimentation. The equigranular aphanitic anhydrite is texturally distinct from that of the nodules and is compatible with a precursor as fine-grained gypsum deposited from spontaneous 'whitings' (Babel, 2004) during episodes of rapid evaporation. By contrast, the clastic laminae resulted from the influx of silt and immature fine sand during wet periods or possibly as aeolian deposits (Gunatilaka \& Shearman, 1988). Thicker evaporite laminae within the succession could be the result of seasonal mixing or of longer arid periods (Babel, 2004). Although the scale of the thinnest laminae is compatible with annual accumulations (varves; Einsele, 2000), Warren (2006) warned that, rather than annual, such lamination may have resulted from repeated flooding events. Flooding events generating sandy siltstones were characteristic of the Ballagan coastal plain according to Bennett et al. (2016) (Fig. 4). The clastic laminae in one of the Hoddom examples have features of sandy siltstone deposited in shallow water.

This article is protected by copyright. All rights reserved 
The characteristics of the brown claystone strips within the upper part of the deformed unit in the Norham core (Figs 7E, 10C and 10D) suggest that these are relicts of a microbial mat. Indirect evidence following Schieber $(1999,2007)$ includes the ragged form of the strips interleaved with anhydrite, randomly orientated clays and micas, dispersed corroded quartz and hornblende grains and the thin discontinuous sheets of carbonaceous matter. Soft-sediment deformation of the whole unit is probably contemporaneous with dehydration of primary gypsum to anhydrite and may have been the cause of mat rupture.

\section{Facies 5: Dolostone - evaporite facies}

Although in many of the dolostones the dolomite has recrystallized, a few examples of primary dolomicrite remain. The presence of interlaminated dolostone and evaporite at the base of some dolomicrite beds (lower part; Fig. 7F) containing dispersed, irregular nodules throughout suggests that the evaporite formed penecontemporaneously with the dolomite in a shallow hypersaline lake or brine pan. Penecontemporaneous crystallization of dolomite and gypsum has been inferred to occur in the coastal salinas of Baja California (Pierre et al., 1984). By contrast, the coalescent, rounded nodules seen in other examples formed above the water table following drying out of the lake, as envisaged for Facies 2a. The water-escape structures in these beds probably resulted from the expulsion of water produced during dehydration of gypsum.

\section{Facies 6: Residue beds}

The residue beds formed through dissolution and carbonate replacement of the evaporites, probably in the near subsurface during Cenozoic or, more recent, uplift. The original bed thickness of these examples was probably insufficient for collapse to have taken place. However, collapse breccia has been illustrated from post-Tournaisian strata in the Lyne Formation near Bewcastle in the Northumberland Basin (Ward, 1997, fig. 4a).

This article is protected by copyright. All rights reserved 


\section{Facies 7: Pseudomorphs after halite}

Displacive halite cubes are a feature of marine marginal sabkhas and salinas, forming at, or a little above, the groundwater table through capillary evaporation (Schreiber \& El Tabakh, 2000). A similar origin is inferred for the sporadic occurrences in the Ballagan Formation.

\section{DISCUSSION}

Ancient evaporite facies are rarely preserved in surface exposures and the immediate subsurface in non-arid regions because of dissolution. Their former presence in exposures of the Ballagan Formation had been recognized from calcite pseudomorphs in some dolostone beds at Burnmouth (Scott, 1986). Furthermore, exposures containing satin spar veins are characteristic only of this formation in the Mississippian succession of the region (Hall et al., 1998; Monro, 1999). However, the importance of evaporites as an integral part of the depositional regime is only apparent through subsurface investigations.

The coastal floodplain model for the Ballagan Formation proposed by Francis et al. (1970), Anderton (1985) and Andrews et al. (1991) has been developed further by Bennett et al. $(2016,2017)$ and Kearsey et al. (2016). Scott (1986) proposed an alternative palaeogeography from studies at Burnmouth (Fig. 1), and postulated that the evaporite rocks formed in sabkhas around the margins of a continental lake. Although there may be some examples of this environment, it is unlikely to be the primary setting, given the sporadic occurrences of storm-derived marine invertebrate fossils across the Midland Valley and the proximity of brachiopod and crinoid-bearing limestones of the partly coeval Lyne Formation in the adjacent Northumberland - Solway Basin (Fig. 2; Leeder, 1975; Waters et al., 2011). The 128 cryptic marine intervals in the Norham core, comprising a stormderived Chondrites ichnofacies and scolecodonts demonstrate abundant marine flooding into the 
Tweed Basin (Bennett et al., 2017). The restricted evaporite mineralogy of dolomite, gypsum and anhydrite along with trace amounts of celestine and barite is more typical of marginal marine than of continental deposits (Warren, 2006; Chagas et al., 2016).

Gypsum $\delta^{34} S$ values of $20 \%$ from the Ballagan Formation in the Midland Valley reported by Pattrick et al. (1983) are close to Tournaisian seawater $\delta^{34} \mathrm{~S}$ values of $21 \pm 1 \%$ (Kampschulte et al., 2001). However, the two Ballagan analyses quoted by Pattrick et al. (1983) are likely to have been from satin spar veins as the samples were from exposures. Therefore, the values quoted may not support the marine origin of the sulphate, because the sulphur isotopes will have undergone fractionation as a result of phase transformation during burial and uplift (Taberner et al., 2002), although the effect of this is often regarded as small (Schreiber \& El Tabakh, 2000). More compelling evidence for the origin of the sulphate is provided by the repeated cryptic marine flooding events (Bennett et al., 2017).

The interpretation here is that Ballagan evaporites formed because of the evaporation of shallow hypersaline lakes. The coastal plain model for the Ballagan Formation (Fig. 12) contains open and closed saline lakes (Bennett et al., 2016, 2017), along with meteoric-fed fresh and brackish water lakes (Williams et al., 2006). The current study envisages that some of the closed, marine-fed saline lakes episodically evaporated to become hypersaline, depositing gypsum. The juxtaposition of lakes with differing salinities is seen today in the Brazilian Pantanal wetlands (Costa et al., 2015), although this setting is not coastal. Many lakes were probably temporary and short lived, though along the margin of the Northumberland - Solway Basin some may have been semi-permanent, as in the Hoddom area. Similar bodies of water probably existed to the west of Glasgow. Marine and freshwater surface flooding events formed and recharged the lakes. Microbial mats developed along some lake margins and perhaps the floors during early stages of a lake's existence. The record of evaporite occurrences across the region (Fig. 1) shows particular concentrations to the western extent of the Midland Valley, at Glenrothes and near Perth in the east, in the Northumberland - 
Solway Basin, and in the Tweed basin. These locations probably reflect ready access for marine floodwaters during short-lived storm surges, or through marine water intrusion through the substrate. Here, there is greater evidence for extensive sabkha adjacent to the lakes, where evaporation led to the growth of gypsum nodules or, in some localities halite cubes, in the floodplain silts.

The preservation of evaporites during the wet season probably resulted from several factors. The common occurrence of cohesive debris flow deposits (Bennett et al., 2016) and the formation of temporary lakes during tropical rainfall events suggest high surface runoff over the low permeability floodplain. This may have resulted in only small dilution effects on the sulphate-saturated groundwater mass beneath the floodplain. Storm surges recharged perennial lakes with saline water. Sediment deposited during the wet season buried existing surfaces and added to lacustrine successions. Some of the perennial lakes may have been meromictic. This was possibly the case, for example, for deposition of the evaporite - siltstone laminites of Facies 4; laminated sediments are characteristic of many meromictic lakes (Babel, 2004). It is also possible that the evaporites formed during drier decadal or longer intervals which promoted preservation; no assessment has been published yet of climate rhythms within the region during the Tournaisian.

\section{Tournaisian evaporites}

Tournaisian evaporites are widespread in the palaeoequatorial British Isles and are also characteristic in successions from regions that would have been in close proximity, including eastern Canada. Further afield, in mainland Europe (including Belgium and Poland), Central Asia (Kazakhstan) and the western North America, Tournaisian evaporites are associated with carbonate successions.

In the British Isles, the thickest succession occurs in the centre of the NorthumberlandSolway Basin, where 1153 m of anhydrite-bearing strata were proved in the Easton No 1 Well, north of Carlisle (Fig. 1; Ward, 1997). Within the succession of carbonate rocks and mudstone about 120 anhydrite beds range from $30 \mathrm{~cm}$ to $7.9 \mathrm{~m}$ thick. Although Ward (1997) correlated the uppermost

This article is protected by copyright. All rights reserved 
part of the anhydrite succession with the upper Chadian - lower Arundian Bewcastle Member of the Lyne Formation, the age of the lower part, which contains some of the thickest evaporite units, is not well-constrained biostratigraphically and probably extends down into the Tournaisian. Ward (1997) considered subaqueous gypsum deposition in salinas as the likely origin for the Easton anhydrite beds. However, thickness of units and inferred widespread subcrop (Fig. 1) suggest that these might be marine deposits. To the east, the occurrence of barite within Permian rocks adjacent to the Ninety Fathom Fault east of Newcastle and of brine flow into historic coal mine workings might suggest that the areal extent of these evaporites is even greater than suggested by Ward (1997) (Younger et al., 2016).

To the south, in Cumbria, thin beds of gypsum are associated with limestone in the Marsett Formation (Rose \& Dunham, 1977) and breccias in the Pinsky Gill Formation at the western end of the Stainmore Basin may have formed through gypsum dissolution (Holliday et al., 1979). On the southern flank of the Askrigg Block in North Yorkshire, $26 \mathrm{~m}$ of laminated anhydrite, dolostone and dolomitic siltstone were proved in the Cominco S2 borehole (Fig. 1, Supplementary Data 1; Arthurton et al., 1988). In Derbyshire, $74 \mathrm{~m}$ of the upper Tournaisian Middleton Dale Anhydrite Formation were proved in the Eyam Borehole (Dunham, 1973; Strank, 1985). The formation consists of thinly interbedded dolostone, mudstone and anhydrite rock, the last lithotype comprising $45 \%$ of the thickness. The thinly interbedded character of the anhydrite rock and dolostone likely represents shallow, marginal marine environment during onlap of the Derbyshire High (Gutteridge, 1987). On the Hathern shelf and in the Widmerpool gulf between Derby and Loughborough, at least $97 \mathrm{~m}$ of nodular evaporite rock within a limestone-dolostone-mudstone succession of the Tournaisian Hathern Anhydrite Formation were proved in the Hathern No. 1 Borehole (Llewellyn \& Stabbins, 1970) and in the Long Eaton No. 1 Borehole (Fig. 1; Supplementary Data 1). Here, Llewellyn \& Stabbins (1970) and Carney et al. (2001) envisaged deposition in sabkhas.

This article is protected by copyright. All rights reserved 
In the south of Ireland, Famennian to Tournaisian times saw a diachronous marine transgression north-eastward on to non-marine strata of 'cementstone' facies (Clayton \& Higgs, 1979; Clayton et al., 1986; Pracht \& Somerville, 2015). Evaporites were proved in the subsurface in the Lough Allen Basin south-west of Enniskillen and near Killeshandra on the margin of the southwest limit of the Longford-Down Massif (Sheridan et al., 1967; Clayton \& Higgs, 1979; Mitchell, 1992; Philcox et al., 1992; Waters et al., 2011). North-west of Lough Neagh, near Draperstown, the Tournaisian to earliest Chadian Altagoan Formation contains evaporite rocks within the $250 \mathrm{~m}$ of peritidal sandstone, siltstone and stromatolitic limestone (Owens et al., 1977; Mitchell, 1997).

On the south side of Belfast Lough, beds and nodules of calcified evaporite occur within the Ballycultra Formation, a succession of about 140 m of siltstone interbedded with thin beds of finegrained sandstone, dolostone and stromatolites (Griffith \& Wilson, 1982; Clayton, 1986). A short distance to the north, the Belfast Harbour Borehole (Fig. 1) penetrated $199.5 \mathrm{~m}$ of thinly interbedded dolostone, limestone, evaporite rock and siltstone; anhydrite comprises $19 \%$ of the thickness, occurring in beds less than $1 \mathrm{~m}$ thick and as masses within dolostone beds (Smith, 1986). The presence of ?Sanguinolites, Serpula, algal framework detritus and structureless micritic pellets were inferred by Smith (1986) to indicate deposition in shallow marine or lagoonal environments.

Along the southern margin of Laurussia in eastern Canada, Tournaisian cementstone facies in the Maritimes Basin, similar to the Ballagan Formation, include halite, gypsum, anhydrite and glauberite in the upper part of the Albert Formation (Horton Group) in New Brunswick (Carter \& Pickerill, 1985), the same unit that in Nova Scotia hosts significant tetrapod fossils (Anderson et al., 2015). The disseminated sulphates, in part replaced by calcite, are associated with an evaporitic lacustrine lithofacies comprising 'shale', siltstone and dolostone. However, these evaporites are on a smaller scale than the Visean Windsor Group in Nova Scotia that contains several hundreds of metres of evaporite deposits (Gibling et al., 2008).

This article is protected by copyright. All rights reserved 
Other equatorial evaporites from this time are not from coastal wetlands. On the southern margin of the Brabant Massif in Belgium, dolostone at the top of the Engihoul Formation is strongly karstified with depressions up to $15 \mathrm{~m}$ deep, and cavities filled with calcite replacements of selenitic gypsum growths and intercalations of crinoidal rudstone (Poty, 2016). In the Pomeranian Basin of NW Poland to the east, anhydrite beds and nodules are associated with black 'shale' and calcareous claystone of the upper Tournaisian Grzybowo Formation, deposited in a restricted lagoonal environment within a carbonate shelf setting (Matyja, 2008). A similar shallow marine and lagoonal setting in the Baltic region produced a succession of carbonate rocks with gypsum and siliciclastic rocks (Witzke, 1990). To the east, the passive margin of the separate continent of Kazakhstan hosted a platform-carbonate succession that contains substantial evaporite deposits (Alexeiev et al., 2015).

On the equatorial western margin of Laurussia, from North Dakota to Alberta and Manitoba, strata laid down in the Williston Basin and Prophet Trough contain nodular and massive anhydrite, halite and dolostone deposited in late Tournaisian times (Stott \& Aitken, 1993; Petty, 2010). These evaporites formed in an arid, marginal marine to supratidal sabkha setting during sea-level regression (Petty, 2010).

\section{Climate implications}

Modern coastal evaporite deposits are characteristically associated with arid or semi-arid climate zones, but also occur in seasonally wet tropical biomes (Warren, 2006, 2010; Ziegler et al., 2003). Evidence cited recently from the Ballagan Formation suggests a tropical, seasonal coastal wetland environment, thus conflicting with previous climate conclusions based on the evaporites alone. No aeolian deposits are known from the Ballagan Formation, but in a succession of dominantly finegrained rocks, recognition would perhaps be difficult. More significantly, Kearsey et al. (2016) described a diverse suite of palaeosols that indicate a floodplain wetland rich in habitats ranging from forest to marsh. Using soil geochemical proxies Kearsey et al. (2016) determined estimates of 
mean annual rainfall of 1000 to $1500 \mathrm{~mm}$, typical of equatorial zones. By contrast, abundant mudcrack horizons, the presence of deep vertic cracks in some of the palaeosols and variable soil alkalinities attest to high rates of evaporation, episodic drying out and periods of alternating wetting and drying in a strongly seasonal climate. This regime is further supported by the form of tree growth rings from woody plants recovered from Ballagan Formation sites in SE Scotland which Falcon-Lang (1999) likened to extant araucarian conifer wood from seasonal equatorial environments. Moreover, dense lycopsid forests and swamps in the Albert Formation (Horton Group) of New Brunswick, and coal mires in the upper Tournaisian Price Formation of Virginia, are evidence of other wetlands that lie along the equatorial Laurussian margin at this time (Kreisa \& Bambach, 1973; Falcon-Lang, 2004; Rygel et al., 2006).

Bennett et al. (2016) interpreted the many thin beds of sandy siltstone that are distributed through the Ballagan Formation as cohesive debris flow deposits generated during frequent flooding events, thus lending further support for seasonal events. The sandy siltstone beds are significant in that they preserve associated tetrapod skeletal elements, along with other vertebrate, invertebrate and plant fossils. These beds overlie desiccated substrates and palaeosols and the floodwaters may have resulted directly from precipitation, though overbank flooding caused by hinterland rainfall is also a possible source. The presence of charcoal in these beds suggests wild fires; a feature of the present-day equatorial seasonal biome. The many thin beds containing short residence colonizations of Chondrites trace makers provides evidence for episodic marine flooding (Bennett et al., 2017). Although the role of eustatic sea-level rises cannot be ruled out entirely as a cause of the flooding, it is more likely that this is related to storm surges in the monsoonal climate regime in the Tournaisian of the region envisaged by Wright (1990) and Falcon-Lang (1999).

Bennett et al. (2016) and Kearsey et al. (2016) interpreted the Ballagan coastal floodplain to have been covered by a mosaic of juxtaposed sedimentary environments hosting vegetated and aquatic habitats. These were subject to change through seasonal flooding events. Tetrapods

This article is protected by copyright. All rights reserved 
inhabited both the vegetated floodplain and floodplain lakes (Clack et al., 2016). The hypersaline lakes and sabkhas interpreted from the abundant evaporite deposits increase the diversity of habitats present on the floodplain though these would have been challenging ones for vertebrate animals. These Ballagan environments developed following the mass extinction events at the end of the Devonian (Kaiser et al., 2015), when vertebrate terrestrialization in the Tournaisian accompanied a change in the terrestrial flora that led to a new fluvial and floodplain architecture (Davies \& Gibling, 2013).

Fragmentation of the southern margin of Laurussia in early Tournaisian times formed a gateway linking the Palaeotethys and Panthalassa oceans and established a monsoonal regime over northern Britain, Nova Scotia and adjacent areas (Wright, 1990; Falcon-Lang, 1999). The formation of evaporites at this time, and in particular the thick succession in the Northumberland - Solway Basin (Ward, 1997), is a direct consequence of this continental juxtaposition. An analogous but larger scale example are the halite and anhydrite deposits that formed on the equatorial margins of Brazil and Africa during initial opening of the Atlantic Ocean in Aptian times. Using fully coupled ocean-atmosphere models Chaboureau et al. (2012) showed that high salinity and aridity developed despite the equatorial location. Ziegler et al. (2003) noted that during Mesozoic and Cenozoic evaporite deposition coincided with seasonal climates, and juxtaposed with coal-forming environments because the continental configuration lead to the existence of shallow, extensive tropical seas and restricted basins.

Today, coastal wetlands with a strongly seasonal climate occupy more than two-thirds of the equatorial region (Morley, 2000), including southern Florida, parts of Central America, the Caribbean, Brazil, west Africa, northern Australia, and south-east Asia. However, evaporites have been described from few of these, and mostly from islands in the Caribbean. The British Virgin Islands, part of the Lesser Antilles, have an average annual rainfall of 1100 to $1200 \mathrm{~mm}$, most of which is delivered during the hurricane season. Hypersaline ponds, associated with mangrove 
forests, occur along the coasts of the islands and those ponds with salinities above $175 \%$ o during the dry season precipitate gypsum (Jarecki \& Walkey, 2006). In these ponds, the influx of seawater is through seepage or marine flooding. In the Bahamas, gypsum precipitates in Big Pond on Eleuthra Island (Glunk et al., 2011), whilst peats are accumulating on the coast of Florida nearby (Platt \& Wright, 1992). Abundant gypsum is associated with lake and marsh clays of coastal lagoons in Belize (Rejmankova et al., 1996) and with thrombolites in Los Roques National Park, offshore Venezuela (Petrash et al., 2012). Gypsum crusts and microbial mats form in the hypersaline Gotomeer in the island of Bonaire, Netherlands Antilles (Kobluk \& Crawford, 1990).

Highly saline wetlands are a feature of the Salum, Gambia and Casamance river estuaries of Senegal and The Gambia, in west Africa. These are caused by seasonally weak or absent freshwater flow in the rivers and extensive saline groundwater intrusion (Barusseau et al., 1985). Although pans constructed close to the rivers today produce salt, to the authors' knowledge, no natural evaporite deposits have been described from this region. A seasonal climate is also present in some parts of equatorial south-east Asia where warm water carbonates are common today and in the Cenozoic in this marine gateway between the Pacific and Indian oceans (Wilson, 2012). However, evaporites are notably absent, possibly because of the high freshwater run-off from the surrounding landmasses and the lower sea salinity levels.

Some aspects of the sedimentology of the Ballagan Formation resemble those seen today in the Tigris-Euphrates delta (Aqrawi \& Evans, 1994). However, the evidence cited above for a monsoonal regime in the region would seem to rule out the possibility that the Ballagan Formation floodplain represents a 'wetland within a dryland' environment with the common occurrence of salinas supplied by episodic influx of river water (Tooth \& McCarthy, 2007; Pigati et al., 2014). Wetlands in arid regions experience much lower rainfall than that determined for the Ballagan Formation by Kearsey et al. (2016).

This article is protected by copyright. All rights reserved 
Though coastal wetland evaporites are forming today in seasonal equatorial regions, there appear to be few examples described from the geological record. Gastaldo et al. (2006) suggested that the rarity of coastal marsh successions, for example, might be because of poor preservation potential. However, palustrine limestones are not rare: selected examples include from the Jurassic and Cenozoic of the UK (Andrews, 1986; Armenteros \& Edwards, 2012), from the late Mississippian of Kentucky (Barnett et al., 2012) and from the upper Devonian in the Northwest Territories of Canada (MacNeil \& Jones, 2006). Gypsum is only a minor component in these successions. By contrast, from the Mid to Late Jurassic, evaporites formed seaward of coal swamps in Algeria, similar to the situation in the Bahamas and Florida today (Ziegler et al., 2003). The Lower Cretaceous, Leza Formation of the Cameros Basin, northern Spain (Suarez-Gonzalez et al., 2015) is an example of a coastal wetland succession with a diverse range of palaeoenvironments, like the Ballagan Formation, and including evaporitic lakes that deposited dolostone with gypsum. However, only the Canadian and Algerian examples were in equatorial locations at the time of deposition. The Ballagan Formation is therefore an unusual example in the geological record of a tropical, seasonal, coastal wetland that contains an abundance of evaporite forms and facies.

\section{CONCLUSIONS}

Small-scale evaporite deposits are a widespread and important facies of the coastal wetlands of equatorial Laurussia. They occur throughout the 13 million years spanned by the Tournaisian Ballagan Formation. The evaporites of Britain, Ireland and eastern Canada are apparently unique among widespread Tournaisian deposits in that they formed in an equatorial, strongly seasonal coastal wetland. There are few examples in the geological record and these Tournaisian deposits represent an unusual palaeoenvironment that is rarely preserved. Elsewhere, Tournaisian evaporites are associated with marginal marine to shallow marine carbonate systems.

This article is protected by copyright. All rights reserved 
In northern Britain, thin beds of laminated anhydrite, along with nodular gypsum and anhydrite (typically less than 1 to 2 m thick) occur locally throughout the Ballagan Formation in the Midland Valley, in the Tweed Basin and along the northern margin of the Northumberland - Solway basin. In this last example, anhydrite successions reaching $>1000 \mathrm{~m}$ characterize the depocentre indicating the importance and long-lived development of evaporites.

The evaporite deposits represent the existence of ephemeral brine pans to semi-permanent hypersaline lakes or salinas on the floodplain, though some also formed in the subsurface of widespread surrounding sabkhas. Monsoon storms may have initiated and recharged the lakes, directly from precipitation and run-off, and importantly through the addition of marine waters during storm surges. These evaporites are compatible with a strongly seasonal climate for the region that has been proposed elsewhere from palaeosol types and geochemical proxies, and from palaeobotanical evidence. The thickness and extent of these Mississippian examples suggest that salinas and sabkhas were a significant component of this palaeoequatorial setting.

This research shows that the presence of small-scale evaporite deposits in the rock record do not necessarily imply an arid or semi-arid climate. The implications for current understanding of the palaeoenvironment and palaeoclimate in the Tournaisian are appreciated only alongside additional evidence from, for example, palaeosols. The widespread presence increases the diversity and complexity of habitats across large areas of the Tournaisian palaeoequatorial region in which the tetrapods first became terrestrialized.

\section{ACKNOWLEDGEMENTS}

This research formed part of the TW:eed Project (Tetrapod World: early evolution and diversification), led by Jenny Clack (University Museum of Zoology, Cambridge) and funded by N.E.R.C. consortium grants to the British Geological Survey (NEJ021067/1) and the Universities of Leicester (NE/J020729/1) and Southampton (NE/J021091/1). The Norham and Hoddom cores are archived in the National Geological Repository at BGS, Keyworth. The support of staff in curation and facilitating access is acknowledged. The paper is based on initial investigations of the evaporites from the Norham and Hoddom cores carried out by RC and FW as projects during their student studies at Leicester and Southampton, respectively. We acknowledge gratefully lan West's extensive support to FW (but to our dismay, he graciously declined to be a co-author). We thank lan West,

This article is protected by copyright. All rights reserved 
Noel Worley, Doug Holliday, lan Somerville, Jim Hendry and an anonymous referee for comments that improved the manuscript. DM, TIK and MAEB publish with the permission of the Executive Director, British Geological Survey (N.E.R.C.).

\section{REFERENCES}

Aleali, M., Rahimpour-Bonab, H., Moussavi-Harami, R. and Jahani, D. (2013) Environment and sequence stratigraphic implications of anhydrite textures: a case from the Lower Triassic of the Central Persian Gulf. J. Asian Earth Sci., 75, 110-125.

Alexeiev, D.V., Cook, H.E., Djenchuraeva, A.V. and Mikolaichuk, A.V. (2015) The stratigraphic, sedimentological and structural evolution of the southern margin of the Kazakhstan continent in the Tien Shan Range during the Devonian to Permian. In: Geological Evolution of Central Asian Basins and the Western Tien Shan Range (Eds M.-F. Brunet, T. McCann and E. R. Sobel). Geol. Soc. London, Spec. Publ., 427, 231-269.

Alonso-Zarza, A.M. (2003) Palaeoenvironmental significance of palustrine carbonates and calcretes in the geological record. Earth-Sci. Rev., 60, 261-298.

Anderson, J.S., Smithson, T., Mansky, C.F., Meyer, T. and Clack, J. (2015) A diverse tetrapod fauna at the base of 'Romer's Gap'. PLoS ONE, 10, 1-27.

Anderton, R. (1985) Sedimentology of the Dinantian of Foulden, Berwickshire, Scotland. Trans. Roy. Soc. Edinb. Earth Sci., 76, 7-12.

Andrews, J.E. (1986) Microfacies and geochemistry of Middle Jurassic algal limestones from Scotland. Sedimentology, 33, 499-520.

Andrews, J.E. and Nabi, G. (1994) Lithostratigraphy of the Dinantian Inverclyde and Strathclyde Groups, Cockburnspath Outlier, East Lothian-North Berwickshire. Scot. J. Geol., 30, 105-119.

Andrews, J.E. and Nabi, G. (1998) Palaeoclimatic significance of calcretes in the Dinantian of the Cockburnspath Outlier (East Lothian-North Berwickshire). Scot. J. Geol., 34, 153-164.

Andrews, J.E., Turner, M.S., Nabi, G. and Spiro, B. (1991) The anatomy of an early Dinantian terraced floodplain: palaeo-environment and early diagenesis. Sedimentology, 38, 271-287.

Aqrawi, A.A.M. and Evans, G. (1994) Sedimentation in the lakes and marshes (Ahwar) of the Tigris Euphrates delta, southern Mesopotamia. Sedimentology, 41, 755-776.

Armenteros, I. and Edwards, N. (2012) Palaeogeographic, palaeoclimatic, palaeohydrological and chemical/biochemical controls on accumulation of late Eocene coastal lacustrine-palustrine limestones, Southern England. Sed. Geol., 281. 101-118.

Armstrong, H.A. and Purnell, M.A. (1993) Thermal maturation of the Lower Carboniferous strata of the Northumberland Troup and Tweed Basin from conodont colour alteration index (DAI) data. Proc. Yorks. Geol. Soc., 49, 335-343.

Arthurton, R.S., Johnson, E.W. and Mundy, D.J.C. (1988) Geology of the country around Settle.

This article is protected by copyright. All rights reserved 
Memoir, British Geological Survey, 1:50 000 geological sheet 60, England and Wales. London, HMSO, $147 \mathrm{pp}$.

Babel, M. (2004) Models for evaporite, selenite and gypsum microbialite deposition in ancient saline basins. Acta Geol. Polonica, 54, 219-249.

Bahniuk, A., McKenzie, J.A., Perri, E., Bontognali, T.R.R., Vögeli, N., Rezende, C.E., Rangel, T.P. and Vasconcelos, C. (2015) Characterization of environmental conditions during microbial Mg-carbonate precipitation and early diagenetic dolomite crust formation: Brejo do Espinho, Rio de Janeiro, Brazil. In: Microbial Carbonates in Space and Time: Implications for Global Exploration and Production (Eds D.W.J. Bosence, K.A. Gibbons, D.P. Le Heron, W.A. Morgan, T. Pritchard and B.A. Vining). Geol. Soc. London, Spec. Publ., 418, 243-259.

Bailey, J.V., Orphan, V.J., Joye, S.B. and Corsetti, F.A. (2009) Chemotrophic microbial mats and their potential for preservation in the rock record. Astrobiology, 9, 843-859.

Barbieri, R., Stivaletta, N., Marinangeli, L. and Ori, G.G. (2006) Microbial signatures in sabkha evaporite deposits of Chott el Gharsa (Tunisia) and their astrobiological implications. Planet. and Space Sci., 54, 726-736.

Barnett, A.J., Wright, V.P. and Crowley, S.F. (2012) Recognition and significance of paludal dolomites: Lake Mississippian, Kentucky, USA. Special Publication of the International Association of Sedimentologists, 45, 477-500.

Barusseau, J.P., Diop, E.H.S. and Saos, J.L. (1985) Evidence of dynamics reversal in tropical estuaries, geomorphological and sedimentological consequences (Salum and Casamance Rivers, Senegal). Sedimentology, 32, 543-552.

Bateman, R.M. and Scott, A.C. (1990) A reappraisal of the Dinantian floras at Oxroad Bay, East Lothian, Scotland. 2. Volcanicity, palaeoenvironments and palaeoecology. Trans. Roy. Soc. Edinb. Earth Sci., 81, 161-194.

Bennett, C.E., Howard, A.S., Davies, S.J., Kearsey, T.I., Millward, D., Brand, P.J., Browne, M.A.E., Reeves, E.J. and Marshall, J.E.A. (2017) Ichnofauna record cryptic marine incursions onto a coastal floodplain at a key early Mississippian tetrapod site. Palaeogeogr., Palaeoclimatol., Palaeoecol., 468, 287-300.

Bennett, C.E., Kearsey, T.I., Davies, S.J., Millward, D., Clack, J.A., Smithson, T.R. and Marshall, J.E.A. (2016) Early Mississippian sandy siltstones preserve rare vertebrate fossils in seasonal flooding episodes. Sedimentology, 63, 1677-1700.

Bond, D.P.G. and Wignall, P.B. (2010) Pyrite framboids study of marine Permian-Triassic boundary sections: a complex anoxic event and its relationship to contemporary mass extinction. Geol. Soc. Amer. Bull., 122, 1265-1279.

Bontognali, T.R.R., Vasconcelos, C., Warthmann, R.J., Bernasconi, S.M., Dupraz, C., Stromenger, C.J. and McKenzie, J.A. (2010) Dolomite formation within microbial mats in the coastal sabkha of Abu Dhabi (United Arab Emirates). Sedimentology, 57, 824-844.

This article is protected by copyright. All rights reserved 
Browne, M.A.E. (1980) The Upper Devonian and Lower Carboniferous (Dinantian) of the Firth of Tay, Scotland. Institute of Geological Sciences Report Series 80/9.

Browne, M.A.E., Dean, M.T., Hall, I.H.S., McAdam, A.D., Monro, S.K. and Chisholm, J.I. (1999) A lithostratigraphical framework for the Carboniferous rocks of the Midland Valley of Scotland. British Geological Survey Research Report, RR/99/07.

Burgess, I.C. (1961) The fossil soils of the Upper Old Red Sandstone of South Ayrshire. Trans. Geol. Soc. Glasgow, 24, 138-153.

Butler, G.P., Harris, P.M. and Kendall, C.G.St.C. (1982) Recent evaporites from the Abu Dhabi coastal flats. In: Deposition and Diagenetic Spectra of Evaporites (Eds C.R. Handford, R.G. Loucks and G.R. Davies), SEPM Core Workshop No. 3, Calgary, 33-64.

Carney, J.N., Ambrose, K. and Brandon, A. (2001) Geology of the country between Loughborough, Burton and Derby. Sheet Description of the British Geological Survey, 1:50 000 Sheet 141 Loughborough (England and Wales), $92 \mathrm{pp}$.

Carter, D.C. and Pickerill, R.K. (1985) Algal swamp, marginal and shallow evaporitic lacustrine lithofacies from the Late Devonian - early Carboniferous Albert Formation, southeastern New Brunswick, Canada. Atlantic Geology, 21, 69-86.

Cater, J.M.L., Briggs, D.E.G. and Clarkson, E.N.K. (1989) Shrimp-bearing sedimentary successions in the Lower Carboniferous (Dinantian) Cementstone and Oil Shale groups of northern Britain. Trans. Roy. Soc. Edinb. Earth Sci., 80, 5-15.

Chaboureau, A.-C., Donnadieu, Y., Sepulchre, P., Robin, C., Guillocheau, F. and Rohais, S. (2012) The Aptian evaporites of the South Atlantic: a climatic paradox? Clim. Past, 8, 1047-1058.

Chagas, A.A.P., Webb, G.E., Burne, R.V. and Southam, G. 2016. Modern lacustrine microbialites: towards a synthesis of aqueous and carbonate geochemistry and mineralogy. Earth-Sci Rev., 162, 338-363.

Chisholm, J.I., McAdam, A.D. and Brand, P.J. (1989) Lithostratigraphical classification of Upper Devonian and Lower Carboniferous rocks in the Lothians. British Geological Survey, Technical Report WA/89/26.

Clack, J.A. (2002) An early tetrapod from 'Romer's Gap'. Nature, 418, 72-76.

Clack, J.A., Bennett, C.E., Carpenter, D.K., Davies, S.J., Fraser, N.C., Kearsey, T.I., Marshall, J.E.A., Millward, D., Otoo, B.K.A., Reeves, E.J., Ross, A.J., Ruta, M., Smithson, K.Z., Smithson, T.R. and Walsh, S.A. (2016) Phylogenetic and environmental context of a Tournaisian tetrapod fauna. Nature Ecology and Evolution, 1, $11 \mathrm{pp}$.

Clayton, G. (1986) Late Tournaisian miospores from the Ballycultra Formation at Cultra, County Down, Northern Ireland. Irish J. Earth Sci., 8, 73-79.

Clayton, G., Graham, J.R., Higgs, K., Sevastopulo, G.D. and Welsh, A. (1986) Late Devonian and early Carboniferous palaeogeography of southern Ireland and southwest Britain. Annales de la Société

This article is protected by copyright. All rights reserved 
géologique de Belgique, 109, 103-111.

Clayton, G. and Higgs, K. (1979) The Tournaisian marine transgression in Ireland. J. Earth Sci., Roy. Dublin Soc., 2, 1-10.

Corfield, S.M., Gawthorpe, R.L., Gage, M., Fraser, A.J. and Besly, B.M. (1996) Inversion tectonics of the Variscan foreland of the British Isles. J. Geol. Soc., London, 153, 17-32.

Costa, M., Telmer, K.H., Evans, T.L., Almeida, T.IR. and Diakun, M.T. (2015) The lakes of the Pantanal: inventory, distribution, geochemistry, and surrounding landscape. Wetlands Ecol. Manage., 23, 19-39.

Coward, M.P. (1993) The effect of Late Caledonian and Variscan continental escape tectonics on basement structure, Paleozoic basin kinematics and subsequent Mesozoic basin development in NW Europe. Geol. Soc. London Petrol. Geol. Conf., 4, 1095-1108.

Davies, N. S. and Gibling, M. R. (2013) The sedimentary record of Carboniferous rivers: continuing influence of land plant evolution on alluvial processes and Palaeozoic ecosystems. Earth-Sci Rev., 120, 40-79.

Day, J.B.W. (1970) Geology of the country around Bewcastle. Memoir, Geological Survey, Great Britain, England and Wales Sheet 12. 357 pp. HMSO.

Dean, M.T. (1997) Faunas from and biostratigraphy of the BGS Hoddom boreholes 1 and 2, Ecclefechan, Dumfriesshire. British Geological Survey Technical Report WH/97/115.

Domeier, M. and Torsvik, T.H. (2014) Plate tectonics in the late Paleozoic. Geosci. Front., 5(3), 303350 .

Dunham, K.C. (1973) A recent deep borehole near Eyam, Derbyshire. Nature, Phys. Sci., 241, 84-85.

Einsele, G. (2000) Sedimentary Basins: Evolution, Facies and Sedimentary Budget. 2nd edn. Springer, Belin-Heidelberg, 792 pp.

Eyles, V.A., Simpson, J.B. and MacGregor A.G. (1949) Geology of Central Ayrshire. Memoir, Geological Survey, Scotland (sheet 14). $2^{\text {nd }}$ edn. HMSO, Edinburgh, $160 \mathrm{pp}$.

Falcon-Lang, H.J. (1999) The Early Carboniferous (Courceyan-Arundian) monsoonal climate of the British Isles: evidence from growth rings in fossil woods. Geol. Mag., 136, 177-187.

Falcon-Lang, H.J. (2004) Early Mississippian lycopsid forests in a delta-plain setting at Norton, near Sussex, New Brunswick, Canada. J. Geol. Soc. London, 161, 969-981.

Francis, E.H., Forsyth, I.H., Read, W.A. and Armstrong, M. (1970) The Geology of the Stirling district. Memoir Geological Survey, Scotland (sheet 39). HMSO, Edinburgh.

Frantz, C.M., Petryshyn, V.A. and Corsetti, F.A. (2015) Grain trapping by filamentous cyanobacterial and algal mats: implications for stromatolite microfabrics through time. Geobiology, 13, 409-423.

Gastaldo, R.A., Gibson, M.A. and Blanton-Hooks, A. (2006) A Late Mississippian back-barrier marsh

This article is protected by copyright. All rights reserved 
ecosystem in the Black Warrior and Appalachian Basins. In: Wetlands through Time (Eds S.F. Greb and W.A. DiMichele), Geol. Soc. Am. Spec. Publ., 399, 139-154.

Gawthorpe, R.L., Gutteridge, P. and Leeder, M.R. (1989) Late Devonian and Dinantian basin evolution in northern England and North Wales. In: The Role of Tectonics in Devonian and Carboniferous Sedimentation in the British Isles (Eds R.S. Arthurton, P. Gutteridge and S.C. Nolan), Occasional Publ. Yorks. Geol. Soc., 6, 1-24.

Gibling, M.R., Culshaw, N., Rygel, M.C. and Pascucci, V. (2008) Chapter 6: The Maritimes Basin of Atlantic Canada: basin creation and destruction in the collisional zone of Pangea. In: Sedimentary Basins of the World: The Sedimentary Basins of the United States and Canada (Ed. A.D. Miall), 5, 211244.

Glunk, C., Dupraz, C., Braissant, O., Gallagher, K.L., Verrecchia, E.P. and Visscher, P.T. (2011) Microbially mediated carbonate precipitation in a hypersaline lake, Big Pond (Eleuthera, Bahamas). Sedimentology, 58, 720-738.

Gregg, J.M., Bish, D.L., Kaczmarek, S.E. and Machel, H.G. (2015) Mineralogy, nucleation and growth of dolomite in the laboratory and sedimentary environment: a review. Sedimentology, 62, 17491769.

Greig, D.C. (1988) Geology of the Eyemouth district. Memoir British Geological Survey, Scotland (sheet 34). HMSO, London, 78pp.

Griffith, A.E. and Wilson, H.E. (1982) Geology of the country around Carrickfergus and Bangor. Memoir Geological Survey Northern Ireland (sheet 29). HMSO, Belfast, 118 pp.

Gunatilaka, H.A. and Shearman, D.J. (1988) Gypsum-carbonate laminites in a recent sabkha, Kuwait. Carbonates and Evaporites, 3, 67-73.

Gutteridge, P. (1987) Dinantian sedimentation and the basement structure of the Derbyshire Dome. Geol. J., 22, 25-41.

Hall, I.H.S., Browne, M.A.E. and Forsyth, I.H. (1998) Geology of the Glasgow district. Memoir Geological Survey, Scotland (sheet 30E). HMSO, London, 117 pp.

Hird, K. and Tucker, M.E. (1988) Contrasting diagenesis of two Carboniferous Oolites from South Wales: a tale of climatic influence. Sedimentology, 35, 587-602.

Holliday, D.W. (1970) The petrology of secondary gypsum rocks: a review. J. Sed. Petrol., 40, 734744.

Holliday, D.W. (1973) Early diagenesis in nodular anhydrite rocks. Trans. Inst. Mining Metal., 82, B81-B84.

Holliday, D.W., Neves, R. and Owens, B. (1979) Stratigraphy and palynology of early Dinantian (Carboniferous) strata in shallow boreholes near Ravenstonedale, Cumbria. Proc. Yorks. Geol. Soc., 42, 343-356.

Hovorka, S. (1992) Halite pseudomorphs after gypsum in bedded anhydrite - clue to gypsum-

This article is protected by copyright. All rights reserved 
anhydrite relationships. J. Sed. Petrol., 62, 1098-1111.

Irwin, H. (1980) Early diagenetic carbonate precipitation and pore fluid migration in the Kimmeridge Clay of Dorset, England. Sedimentology, 27, 577-591.

Irwin, H., Curtis, C. and Coleman, M. (1977) Isotopic evidence for source of diagenetic carbonates formed during burial of organic-rich sediments. Nature, 269, 209-213.

Jarecki, L. and Walkey, M. (2006) Variable hydrology and salinity of salt ponds in the British Virgin Islands. Saline Systems, 2, 15 pp.

Kaiser, S.I., Aretz, M. and Becker, R.T. (2015) The global Hangenberg Crisis (Devonian-Carboniferous transition): review of a first-order mass extinction. In: Devonian Climate, Sea Level and Evolutionary Events (Eds R.T. Becker, P. Königshof and C.E. Brett), Geol. Soc. London Spec. Publ., 423, 423-429.

Kampschulte, A., Bruckschen, P. and Strauss, H. (2001) The sulphur isotope composition of trace sulphates in Carboniferous brachiopods: implications for coeval seawater, correlation with other geochemical cycles and isotope stratigraphy. Chem. Geol., 175, 149-173.

Kasprzyk, A. and Orti, F. (1998) Palaeogeographic and burial controls on anhydrite genesis: the Badenian basin in the Carpathian Foredeep (southern Poland, western Ukraine). Sedimentology, 45, 889-907.

Kearsey, T.I., Bennett, C.E., Millward, D., Davies, S.J., Gowing, C.J.B., Kemp, S.J., Leng, M.J., Marshall, J.E.A. and Browne, M.A.E. (2016) The terrestrial landscapes of tetrapod evolution in earliest Carboniferous seasonal wetlands of S.E. Scotland. Palaeogeogr., Palaeoclimatol., Palaeoecol., 457, 52-69.

Kendall, A.C. (1984) Evaporites. In: Facies Models (Ed. R.G. Walker), 2nd edn. Geol. Assoc. Can., pp. 259-296.

Kirkham, A. (1997) Shoreline evolution, aeolian deflation and anhydrite distribution of the Holocene, Abu Dhabi. GeoArabia, 2, 403-416.

Kobluk, D.R. and Crawford, D.R. (1990) A modern hypersaline organic mud- and gypsum-dominated basin and associated microbialites. Palaios, 5, 134-148.

Kreisa, R.D. and Bambach, R.K. (1973) Environments of deposition of the Price Formation (Lower Mississippian) in its type area, southwestern Virginia. Am. J. Sci, 273A, 326-342.

Leeder, M.R. (1971) Initiation of the Northumberland Basin. Geol. Mag., 108, 511-516.

Leeder, M.R. (1974) Origin of the Northumberland Basin. Scot. J. Geol., 10, 283-296.

Leeder, M.R. (1975) Lower Border Group (Tournaisian) limestones from the Northumberland Basin. Scot. J. Geol., 11, 151-167.

Leeder, M.R. (1976) Palaeogeographic significance of pedogenic carbonates in the topmost Upper Old Red Sandstone of the Scottish Border Basin. J. Geol., 11, 21-28.

This article is protected by copyright. All rights reserved 
Leeder, M.R. and Bridges P.H. (1978) Upper Old Red Sandstone near Kirkbean, Dumfries and Galloway. Scot. J. Geol., 14, 267-272.

Leeder, M.R., Fairhead, D., Lee, A., Stuart, G., Clemmey, H., El Haddaheh, B. and Green, C. (1989) Sedimentary and tectonic evolution of the Northumberland Basin. In: The Role of Tectonics in Devonian and Carboniferous sedimentation in the British Isles (Eds R.S. Arthurton, P. Gutteridge and S.C. Nolan), Occasional Publ. Yorks. Geol. Soc., 6, 207-223.

Llewellyn, P.G. and Stabbins, R. (1970). The Hathern Anhydrite Series, Lower Carboniferous, Leicestershire, England. Trans. Inst. Mining Metal., B79, 1-15.

Lumsden, G.I., Tulloch, W., Howells, M.F. and Davies, A. (1967) The geology of the neighbourhood of Langholm. Memoir of the Geological Survey, Scotland (Sheet 11).

MacNeil, A.J. and Jones, B. (2006) Palustrine deposits on a late Devonian coastal plain - sedimentary attributes and implications for concepts of carbonate sequence stratigraphy. J. Sed. Res., 76, 292309.

Mastandrea, A., Perri, E., Russo, F., Spadafora, A. and Tucker, M. (2006) Microbial primary dolomite from a Norian carbonate platform, northern Calabria, southern Italy. Sedimentology, 53, 465-480.

Matyja, H. (2008) Pomeranian basin (NW Poland) and its sedimentary evolution during Mississippian times. Geol. J., 43, 123-150.

Miller, H. (1887) The geology of the country around Otterburn and Elsdon. Memoir Geological Survey, England and Wales (sheet 8). HMSO, London, 147pp.

Millward, D., Kearsey, T.I. and Browne, M.A.E. (2013) Norham West Mains Farm Borehole: operations report. British Geological Survey Internal Report, IR/13/033. 39 pp.

Mitchell, W.I. (1992) The origin of Upper Palaeozoic sedimentary basins in Northern Ireland and relationships with the Canadian Maritime provinces. In Basins on the Atlantic Seaboard: Petroleum Geology, Sedimentology and Basin Evolution (Ed. J. Parnell), Geol. Soc. London Spec. Publ., 62, 191202.

Mitchell, W.I. (1997) Geological description of the area around Moneyneany (1:10 000 sheet 77NW Quadrant). Geological Survey of Northern Ireland Technical Report, GSNI/97/2.

Monro, S.K. (1999) Geology of the Irvine district. Memoir British Geological Survey, Scotland (sheet $22 \mathrm{~W}$ and part of 21E). HMSO, London.

Morley, R.J. (2000) Origin and Evolution of Tropical Rainforests. Wiley, New York, 362 pp.

Murray, R.C. (1964) Origin and diagenesis of gypsum and anhydrite. J. Sed. Petrol., 34, 512-523.

Ogniben, L. (1957) Secondary gypsum of the sulphur series, Sicily, and the so-called integration. J. Sed. Petrol., 27, 64-79.

Owens, B., Gueinn, K.J. and Cameron, I.B. (1977) A Tournaisian miospore assemblage from the Altagoan Formation (Upper Calciferous Sandstone), Draperstown, Northern Ireland. Pollen et Spores, 
$19,313-324$.

Paterson, I.B. and Hall, I.H.S. (1986) Lithostratigraphy of the late Devonian and early Carboniferous rocks in the Midland Valley of Scotland. British Geological Survey, Report, 18, No 3, 14pp.

Pattrick, R.A.D., Coleman, M.L. and Russell M.J. (1983) Sulphur isotopic investigation of vein leadzinc mineralization at Tyndrum, Scotland. Mineralium Deposita, 18, 477-485.

Petrash, D.A., Gingras, M.K., Lalonde, S.V., Orange, F., Pecoits, E. and Konhauser, K.O. (2012) Dynamic controls on accretion and lithification of modern gypsum-dominated thrombolites, Los Roques, Venezuela. Sed. Geol., 245-246, 29-47.

Petty, D.M. (2010) Sequence stratigraphy and sequence boundary characteristics for upper Tournaisian (Mississippian) strata in the greater Williston basin area: an analysis of a third order cratonic carbonate-evaporite depositional cycle. Bull. Canadian Petrol. Geol., 58, 375-402.

Philcox, M.E., Baily, H., Clayton, G. and Sevastopulo, G. (1992) Evolution of the Carboniferous Lough Allen Basin, Northwest Ireland. In: Basins on the Atlantic seaboard: petroleum geology, sedimentology and basin evolution (Ed. J. Parnell), Geol. Soc. London Spec. Publ., 62, 203-215.

Pierre, C., Ortlieb, L. and Person, A. (1984) Supratidal evaporitic dolomite at Ojo de Liebre Lagoon: mineralogical and isotopic arguments for primary crystallization. J. Sed. Petrol., 54, 1049-1061.

Pigati, J.S., Rech, J.A., Quade, J. and Bright, J. (2014) Desert wetlands in the geological record. EarthSci Rev., 132, 67-81.

Platt, N.H. and Wright, V.P. (1992) Palustrine carbonates and the Florida Everglades: towards an exposure index for the freshwater environment. J. Sed.Petrol., 62, 1058-1071.

Poty, E. (2016) The Dinantian (Mississippian) succession of southern Belgium and surrounding areas: stratigraphy improvement and inferred climate reconstruction. Geologica Belgica, 19, 177-200.

Pracht, M. and Somerville, I.D. (2015) A revised Mississippian lithostratigraphy of County Galway (western Ireland) with an analysis of carbonate lithofacies, biostratigraphy, depositional environments and palaeogeographic reconstructions utilising new borehole data. J. Palaeogeogr., 4, $1-26$.

Read, W.A. and Johnson, S.R.H. (1967) The sedimentology of sandstone formations within the Upper Old Red Sandstone and lowest Calciferous Sandstone Measures west of Stirling, Scotland. Scot. J. Geol., 3, 242-267.

Rejmankova, E., Pope, K.O., Post, R. and Maltby, E. (1996) Herbaceous wetlands of the Yucatan Peninsula: communities at extreme ends of environmental gradients. Int. Revue ges. Hydrobiol. Hydrogr., 81, 223-252.

Retallack, G.J. and Dilcher, D.L. (1988) Reconstructions of selected seed ferns. Ann. Miss. Bot. Gar., 75, 1010-1057.

Rose, W.C.C. and Dunham, K.C. (1977) Geology and hematite deposits of South Cumbria. Econ. Mem. Geol. Surv. G.B. England and Wales sheet 58 and part 48, 170 pp.

This article is protected by copyright. All rights reserved 
Rygel, M.C., Calder, J.H., Gibling, M.R., Gingras, M.K. and Melrose, C.S.A. (2006) Tournaisian forested wetlands in the Horton Group of Atlantic Canada. In: Wetlands Through Time (Eds S.F. Greb and W.A. DiMichele), Geol. Soc. America, Special Paper, 399, 103-126.

Sánchez-Román, M., McKenzie, J.A., Rebello Wagener, A.deL., Rivadeneyra, M.A. and Vasconcelos, C. (2009) Presence of sulfate does not inhibit low-temperature dolomite precipitation. Earth Planet Sci. Lett., 285, 131-139.

Sanz-Montero, M.E., Rodríguez-Aranda, J.P. and García del Cura, M.A. (2009) Bioinduced precipitation of barite and celestite in dolomitic microbialites: examples from Miocene lacustrine sequences in the Madrid and Duero Basins, Spain. Sed. Geol., 222, 138-148.

Sanz-Rubio, E., Hoyos, M., Calvo, J.P. and Rouchy, J.M. (1999) Nodular anhydrite growth controlled by pedogenic structures in evaporite lake formations. Sed. Geol., 125, 195-203.

Schieber, J. (1999) Microbial mats in terrigenous clastics: the challenge of identification in the rock record. Palaios, 14, 3-12.

Schieber, J. (2007) Microbial mats on muddy substrates - examples of possible sedimentary features and underlying processes. In: Atlas of Microbial Mat Features Preserved within the Siliciclastic Rock Record. (Eds J. Schieber, P.K. Bose, P.G. Eriksson, S. Banerjee, S. Sarker, W. Altermann and O. Catuneanu), pp. 117-133. Elsevier.

Schreiber, B.C. and El Tabakh, M. (2000) Deposition and early alteration of evaporites. Sedimentology, 47, Suppl. 1, 215-238.

Scott, A.C. and Meyer-Berthaud, B. (1985) Plants from the Dinantian of Foulden, Berwickshire, Scotland. Trans. Roy. Soc. Edinb.: Earth Sci., 76, 13-20.

Scott, W.B. (1986) Nodular carbonates in the Lower Carboniferous, Cementstone Group of the Tweed Embayment, Berwickshire: evidence for a former sulphate evaporite facies. Scot. J. Geol., 22, 325-345.

Shearman, D.J. (1966) Origin of marine evaporites by diagenesis. Trans. Inst. Mining and Metallurgy, B75, 208-215.

Shearman, D.J. (1978) Halite in sabkha environments. In: Marine Evaporites (Eds W.E. Dean and B.C. Schreiber), SEPM Short Course, 4, 30-42.

Shearman, D.J. (1985) Syndepositional and late diagenetic alteration of primary gypsum to anhydrite. In: Sixth International Symposium on Salt (Eds B.C. Schreiber and L. Harmer), 1, 41-50. Salt Institute, Alexandria, VA.

Shearman, D.J. and Fuller, J.G. (1969) Anhydrite diagenesis, calcitization and organic laminites, Winnipegosis Formation, Middle Devonian, Saskatchewan. Bull. Canadian Petrol. Geol., 17, 496-525.

Sheridan, D.J.R., Hubbard, W.F. and Oldroyd, R.W. (1967) A note on Tournaisian strata in Northern Ireland. Roy. Dublin Soc., Sci. Proc., Series A, 3, 33-37.

Sibley, D.F. and Gregg, J.M. (1987) Classification of dolomite rock textures. J. Sed. Petrol., 57, 967-

This article is protected by copyright. All rights reserved 
975.

Smith, R.A. (1986) Permo-Triassic and Dinantian rocks of the Belfast harbour Borehole. British Geological Survey Report, 18, No 6.

Smithson, T.R., Wood, S.P., Marshall, J.E.A. and Clack, J.A. (2012) Earliest Carboniferous tetrapod and arthropod faunas from Scotland populate Romer's Gap. PNAS, 109, 4532-4537.

Stephenson, M.H., Williams, M., Monaghan, A.A., Arkley, S. and Smith, R.A. (2002) Biostratigraphy and palaeoenvironments of the Ballagan Formation (Lower Carboniferous) in Ayrshire. Scot. J. Geol., 38, 93-111.

Stephenson, M.H., Williams, M., Leng, M.J. and Monaghan, A.A. (2004a) Aquatic plant microfossils of probable non-vascular origin from the Ballagan Formation (Lower Carboniferous), Midland Valley, Scotland. Proc. Yorks. Geol. Soc., 55, 145-158.

Stephenson, M.H., Williams, M., Monaghan, A.A., Arkley, S., Smith, R.A., Dean, M., Browne, M.A.E. and Leng, M. (2004b) Palynomorph and ostracod biostratigraphy of the Ballagan Formation, Midland Valley of Scotland, and elucidation of intra-Dinantian unconformities. Proc. Yorks. Geol. Soc., 55, 131-143.

Stott, D.F. and Aitken, J.D. (Eds) (1993) Sedimentary cover of the craton in Canada. Geol. Surv. Canada, Geology of Canada, 5, 825 pp.

Strank, A.R.E. (1985) The Dinantian biostratigraphy of a deep borehole near Eyam, Derbyshire. Geol. J., 20, 227-237.

Suarez-Gonzalez, P., Quijada, I.E., Benito, M.I. and Mas, R. (2015) Sedimentology of ancient coastal wetlands: insights from a Cretaceous multifaceted depositional system. J. Sed. Res., 85, 95-117. DOI:10.2110/jsr.2015.07.

Taberner, C., Marshall, J.D., Hendry, J.P., Pierre, C. and Thirlwall, M.F. (2002) Celestite formation, bacterial sulphate reduction and carbonate cementation of Eocene reefs and basinal sediments (Igualada, NE Spain). Sedimentology, 49, 171-190.

Tooth, S. and McCarthy, T.S. (2007) Wetlands in drylands: geomorphological and sedimentological characteristics, with emphasis on examples from southern Africa. Prog. Phys. Geog., 31, 3-41.

Van der Zwan, C.J., Boulter, M.C. and Hubbard, R.N.L.B. (1985) Climatic change during the lower Carboniferous in Euramerica, based on multivariate statistical analysis of palynological data. Palaeogeogr., Palaeoclimatol., Palaeoecol., 52, 1-20.

Vasconcelos, C. and McKenzie, J.A. (1997) Microbial mediation of modern dolomite precipitation and diagenesis under anoxic conditions (Lagoa Vermelha, Rio de Janeiro, Brazil). J. Sed. Res., 67, 378390.

Ward, J. (1997) Early Dinantian evaporites of the Easton-1 well, Solway Basin, onshore, Cumbria, England. In: Petroleum Geology of the Irish Sea and Adjacent Areas (Eds N.S. Meadows, S.P. Trueblood, M. Hardman and G. Cowan). Geol. Soc. London Spec. Publ., 124, 277-296. 
Warren, J.K. (2000) Dolomite: occurrence, evolution and economically important associations. Earth-Sci Rev., 52, 1-81.

Warren, J.K. (2006) Evaporites: Sediments, Resources and Hydrocarbons. Springer-Verlag, BerlinHeidelberg, 1035 pp.

Warren, J.K. (2010) Evaporites through time: tectonic, climatic and eustatic controls in marine and nonmarine deposits. Earth-Sci. Rev., 98, 217-268.

Warren, J.K. and Kendall, C.G.St.C. (1985) Comparison of sequences formed in marine sabkha (subaerial) and salina (subaqueous) settings: modern and ancient. Amer. Assoc. Petrol. Geol., Bull., 69, 1013-1023.

Waters, C.N., Somerville, I.D., Jones, N.S., Cleal, C.J., Collinson, J.D., Waters, R.A., Besly, B.M., Dean, M.T., Stephenson, M.H., Davies, J.R., Freshney, E.C., Jackson, D.I., Mitchell, W.I., Powell, J.H., Barclay, W.J., Browne, M.A.E., Leveridge, B.E., Long, S.L. and McLean, D. (Eds) (2011) A revised correlation of Carboniferous rocks in the British Isles. Geol. Soc. London Special Report, 26, 186pp.

West, I.M. (1964) Evaporite diagenesis in the Lower Purbeck Beds of Dorset. Proc. Yorks. Geol. Soc., 34, 315-330.

Wilkin, R.T., Barnes, H.L. and Brantley, S.L. (1996) The size distribution of framboidal pyrite in modern sediments: an indicator of redox conditions. Geochim. Cosmochim. Acta, 60, 3897-3912.

Williams, M., Leng, M.J., Stephenson, M.H., Andrews, J.E., Wilkinson, I.P., Siveter, D.J., Horne, D.J. and Vannier, J.M.C. (2006) Evidence that Early Carboniferous ostracods colonised coastal flood plain brackish water environments. Palaeogeogr., Palaeoclimatol., Palaeoecol., 230, 299-318.

Williams, M., Stephenson, M.H., Wilkinson, I.P., Leng, M.J. and Miller, C.G. (2005) Early Carboniferous (Late Tournaisian-Early Viséan) ostracods from the Ballagan Formation, central Scotland, UK. J. Micropal., 24, 77-94.

Wilson, M.E.J. (2012) Equatorial carbonates: an earth systems approach. Sedimentology, 59, 1-31.

Witzke, B.J. (1990) Palaeoclimatic constraints for Palaeozoic palaeolatitutes of Laurentia and Euramerica. In: Palaeozoic Palaeogeography and Biogeography (Eds W.S. McKerrow and C.R. Scotese). Geol. Soc. London, Memoir, 12, 57-73.

Wright, D.T. and Wacey, D. (2005) Precipitation of dolomite using sulphate-reducing bacteria from the Coorong Region, South Australia: significance and implications. Sedimentology, 52, 987-1008.

Wright, V.P. (1982) Calcrete palaeosols from the lower Carboniferous Llanelly Formation, South Wales. Sed. Geol., 33, 1-33.

Wright, V.P. (1990) Equatorial aridity and climatic oscillations during the early Carboniferous, southern Britain. J. Geol. Soc. London, 147, 359-363.

Wright, V.P., Turner, M.S., Andrews, J.E. and Spiro, B. (1993) Morphology and significance of supermature calcretes from the Upper Old Red Sandstone of Scotland. J. Geol. Soc. London, 150, 871-883.

This article is protected by copyright. All rights reserved 
Young, G.M. and Caldwell, W.G.E. (2011) Early Carboniferous stratigraphy in the Firth of Clyde area: new information from the Isle of Bute. Scot. J. Geol., 47, 143-156.

Young, G.M. and Caldwell, W.G.E. (2012) The Northeast Arran Trough, the Corrie conundrum and the Highland Boundary Fault in the Firth of Clyde, SW Scotland. Geol. Mag., 149, 578-589.

Young, J.W. (1867) On the Ballagan Series of Rocks. Trans. Geol. Soc. Glasgow, 2, 209-212.

Younger, P.L, Manning, D.A.C., Millward, D., Busby, J.P., Jones, C. R.C. and Gluyas, J.G. (2016) Geothermal exploration in the Fell Sandstone Formation (Mississippian) beneath the city centre of Newcastle upon Tyne, UK: the Newcastle Science Central Deep Geothermal Borehole. Quart. J. Eng. Geol. Hydrogeol., 49, 350-363.

Ziegler, A.M., Eshel, G., Rees, P.M., Rothfus, T.A., Rowley, D.B. and Sunderlin, D. (2003) Tracing the tropics across land and sea: Permian to present. Lethaia, 36, 227-254.

\section{Figures}

Fig. 1. Distribution of Tournaisian and evaporite rocks in the Midland Valley of Scotland and Northumberland - Solway Basin. Key boreholes are shown; Com S2 - Cominco S2. Borehole metadata are given in Supplementary Data 1. Ballagan Formation outcrop from the British Geological Survey DiGMapGB @ NERC 2015. Concealed evaporite subcrop in the Northumberland Solway Basin after Ward (1997).

Fig. 2. Lower Mississippian stratigraphy in the Midland Valley of Scotland and Northumberland Solway Basin (after Waters et al., 2011); KCBV - Kelso, Cottonshope and Birrenswark volcanic formations. Ballagan Formation (Browne, 1980) subsumes the Tyninghame Formation (Chisholm et al., 1989), Cementstone Group (Miller, 1887; Greig, 1988) and part of the Lower Border Group (Lumsden et al., 1967; Day, 1970; Leeder, 1974). The Kinnesswood, Ballagan and Clyde Sandstone formations comprise the Inverclyde Group (Browne et al., 1999). The palynostratigraphy of the Ballagan Formation is from Stephenson et al. (2002, 2004a,b), Williams et al. (2005) and Smithson et al. (2012).

Fig. 3. Distribution of evaporite occurrences in selected boreholes in the west and north of the 
Midland Valley of Scotland. The black curves within the stratigraphical columns represent the proportional thickness of grey, laminated siltstone/ mudstone per $10 \mathrm{~m}$ interval through the succession.

Fig. 4. Lithological logs and stratigraphical distribution of sedimentary characteristics of the Ballagan Formation in the Norham and Hoddom borehole cores. Main fluvial sandstone units in yellow. Note difference in scale between the logs.

Fig. 5. Photomicrographs of evaporite textures from the Norham West Mains Farm and Hoddom cores; (A) to (F) in crossed-polars. (A) Lozenge-shaped pseudomorphs of anhydrite after gypsum in very fine-grained sandstone cemented by anhydrite. Hoddom, depth $160.61 \mathrm{~m}$. SSK70688. Field of view $2 \mathrm{~mm}$. (B) Packed pseudomorphs of anhydrite after gypsum in dark dolomicrite matrix. Hoddom, depth $169.00 \mathrm{~m}$. SSK70687. Field of view $3.3 \mathrm{~mm}$. (C) Aphanitic cores and subparallelaligned anhydrite in coalesced nodular mass within dolostone bed. Norham, depth $448.85 \mathrm{~m}$. SSK38034. Field of view $2 \mathrm{~mm}$. (D) Margin of nodular mass with interlayering of aphanitic anhydrite aggregates with host siltstone. Some of the anhydrite aggregates resemble gypsum crystal forms. Facies 2 at depth $467.90 \mathrm{~m}$, Norham. SSK55670. Field of view $3.3 \mathrm{~mm}$. (E) Aphanitic anhydrite in smaller nodules and around margin of larger mass, the centre of which is composed of granoblastic anhydrite (top). From Facies 2 at depth 493.54 m, Norham. SSK55673. Field of view 3.3 mm. (F) Granoblastic texture in anhydrite rock. Same unit as D, Norham depth $467.84 \mathrm{~m}$. SSK55670. Field of view $3.3 \mathrm{~mm}$.

Fig. 6. Sedimentary log illustrating the context of the evaporites in the saline - hypersaline lake facies association; Norham core, depth 445.84 to $451.58 \mathrm{~m}$ : (A) to (F) refer to photographs in Fig. 7.

Fig. 7. Core images for evaporite-bearing units in Fig. 6. (A) Facies 2b; (B) and (C) Facies 5; (D) Facies 1 (top and third from top) and Facies 5; (E) Facies 4; (F) Facies 5. All cores are $102 \mathrm{~mm}$ across.

This article is protected by copyright. All rights reserved 
Fig. 8. Selected examples of evaporite facies from the Ballagan Formation. All except for (C) are from the Norham core, width of core and image $102 \mathrm{~mm}$; (C) from the Hoddom core, width $46 \mathrm{~mm}$; all depths are given below ground level. (A) Facies 1a, nodular anhydrite, depth 474.40 to $474.60 \mathrm{~m}$. (B) Facies 1a, enterolithic vein, depth 468.05 to $468.16 \mathrm{~m}$. (C) Facies $1 \mathrm{~b}$, beds of small nodules in finegrained sandstone, depth 135.81 to $135.92 \mathrm{~m}$. (D) Facies 3, pink nodular gypsum within dolomicrite matrix, cut by white gypsum veins; note thin unit of laminated dolomicrite beneath upper gypsum vein separating two nodule beds; depth 182.42 to $182.85 \mathrm{~m}$. (E) Anhydrite rock zone with stylolitic contact and traces of siltstone between nodules, Facies 2, 377.99 to $378.10 \mathrm{~m}$. (F). Facies 5, ferroan dolostone containing anhydrite nodules; water escape structure at top of unit, depth 482.06 to $482.27 \mathrm{~m}$. (G) Facies 4, alternating millimetric lamination in siltstone and anhydrite rock, depth 450.76 to $450.83 \mathrm{~m}$;

Fig. 9. Examples of Facies 2 from the Norham core (core width $102 \mathrm{~mm}$ ). (A) Facies 2a, including separated nodular, anhydrite rock and protonodular zones. Note the water-escape structure at the top of the dolostone hosting the nodular zone. The protonodular zone is hosted in laminated siltstone and dolomitic siltstone. Depth 422.14 to $422.94 \mathrm{~m}$. (B) Facies $2 \mathrm{~b}$, showing nodular and chicken-wire zones. At the top, the protonodular zone is weakly developed. Depth 436.98 to $437.38 \mathrm{~m}$. (C) Facies 2a (322.70 to $323.37 \mathrm{~m}$ ) overlain by Facies 5 dolostone with evaporite nodules. Most of the evaporite mineral is secondary gypsum but the well-defined nodular, anhydrite rock and protonodular zones are present in Facies 2 . The protonodular zone at the base is hosted by laminated dolostone. Central section of core is polished to reveal textures.

Fig. 10. Sedimentary features indicating the former presence of microbial mats in the Ballagan Formation. All depths given beneath ground level. (A) Protonodules of gypsum (gy) with rims of poikilotopic dolomite in interlaminated siltstone and very fine-grained sandstone at the base of Facies $2 \mathrm{a}$. The dark laminae deformed by the protonodules are composed of planar-s to planar-e dolomite rhombs that are detailed in B. Largest protonodule is $6 \mathrm{~mm}$ across. Norham core, depth 
$422.65 \mathrm{~m}$. Scan of thin section SSK55656. Field of view $30 \mathrm{~mm}$. (B) Electron backscatter image of detail of one of the dark dolomite laminae in (A). Note thin films of clay minerals (c) associated with fine-grained pyrite (bright specks) and floating grains of quartz (q). Pore-fills of anhydrite (a) are also present. (C) Disrupted and torn strips of claystone (dark layers) interleaved with aphanitic anhydrite (pale areas). Facies 4, Norham, depth $450.70 \mathrm{~m}$. Rectangle indicates location of (D). Field of view $26 \mathrm{~mm}$ across. Scan of thin section SSK70682. (D) Detail from right-hand side of (C) in plane-parallel light showing brownish clay-rich layers alternating with pale anhydrite dominated layers. The claystone laminae contain narrow strips of carbonaceous matter, scattered quartz and feldspar grains, pockets of anhydrite and randomly orientated mica plates. Field of view $2 \mathrm{~mm}$. (E) and (F) Electron backscatter images of pyrite-rich (bright trails and specks) dolostone hosting protonodules of secondary gypsum (gy) with rims of planar-e dolomite (d). In (E), the arrows indicate the margin of the gypsum nodule bed. Norham core, depth $182.42 \mathrm{~m}$. SSK55666. (F) Detail of (E) showing the mesh-like pyrite trails outlining the former presence of tubular structures interpreted as possible microbial filaments. Note the pyrite framboids $(p)$ and entrapped grains of mica $(m)$ and quartz (q).

Fig. 11. Secondary evaporite textures from the Norham West Mains Farm and Hoddom cores: (A) to (F) in crossed-polars. (A) Porphyrotopic gypsum (gy) with abundant anhydrite inclusions at margin of anhydrite (An) nodule. Matrix siltstone cut by gypsum vein. Norham, depth 421.54 m. SSK61191. Field of view $3.3 \mathrm{~mm}$. (B) Gypsum (gy) nodules in dark dolomicrite (top right); rim to nodule of polymodal planar-e to planar-s dolomite. Norham, depth $182.61 \mathrm{~m}$. SSK55666. Field of view $3.3 \mathrm{~mm}$. (C) Porphyrotopic gypsum with anhydrite inclusions replaced by finer grained anhedral gypsum and overprinted by variable amounts of dolomite. Norham depth $377.71 \mathrm{~m}$. SSK55651. Field of view $3.3 \mathrm{~mm}$. (D) Gypsum nodules (gy) within laminated dolomicrite containing streaks of organic matter (c); granular gypsum vein to left. Norham depth $182.76 \mathrm{~m}$. SSK55668. Field of view $3.3 \mathrm{~mm}$. (E) Anhydrite vein, cutting anhydrite nodules ( $\mathrm{n}$ ) and silty dolostone (s); nodules heavily overprinted with polymodal planar-s dolomite. Norham depth $451.39 \mathrm{~m}$. SSK61185. Field of view $3.3 \mathrm{~mm}$. (F) Poikilotopic anhydrite cement in very fine-grained sandstone beneath dolomicrite with nodular 
anhydrite. Hoddom, depth $169.43 \mathrm{~m}$. SSK42175. Field of view $1.5 \mathrm{~mm}$.

Fig. 12. Cartoon to illustrate the evaporite palaeoenvironments.

Table 1. Summary of the petrographic characteristics of the evaporite forms in the Ballagan Formation.

Table 2. Summary of the diagenesis of the evaporite rocks in the Ballagan Formation. References cited support the interpretation except for 8 and 10 which are specific to these rocks.

\section{Supplementary Data}

1. Summary data for boreholes penetrating Tournaisian rocks in the UK.

2. Evaporite occurrences in the Norham cores.

3. Evaporite occurrences in the Hoddom cores.

This article is protected by copyright. All rights reserved 
Table 1. Summary of the petrographic characteristics of the evaporite forms in the Ballagan Formation.

\begin{tabular}{|c|c|c|c|c|c|c|}
\hline Evaporite form & Description & Host rock and associated evaporite forms & Facies & Anhydrite texture & Gypsum textures & Dolomite texture \\
\hline $\begin{array}{l}\text { Pseudomorphs } \\
\text { after halite }\end{array}$ & $\begin{array}{l}\text { Disseminated euhedral and } \\
\text { hopper crystals replaced in silt } \\
\text { and sand }\end{array}$ & $\begin{array}{l}\text { Siltstone and laminated fine-grained } \\
\text { sandstone. Not associated with other facies }\end{array}$ & 7 & Not present & Not present & Not present \\
\hline $\begin{array}{l}\text { Pseudomorphs } \\
\text { after primary } \\
\text { gypsum }\end{array}$ & $\begin{array}{l}\text { Euhedral and subhedral shapes to } \\
\text { anhydrite aggregates up to } 3 \mathrm{~mm}\end{array}$ & Sandstone, dolostone and siltstone & 4 & Aphanitic aggregates & Not seen & Generally not overprinted \\
\hline Protonodules & $\begin{array}{l}<5 \mathrm{~mm} \text { diameter gypsum and } \\
\text { anhydrite typically lying along } \\
\text { lamination; also as dispersed, } \\
\text { angular, irregular-shaped masses }\end{array}$ & $\begin{array}{l}\text { Grey laminated siltstone, silty dolostone and } \\
\text { dolostone; very thin dolomicrite laminae } \\
\text { associated with protonodules }\end{array}$ & 2 & $\begin{array}{l}\text { Aphanitic aggregates, some forms } \\
\text { reminiscent of single gypsum crystals; } \\
\text { inclusions in secondary gypsum } \\
\text { protonodules }\end{array}$ & $\begin{array}{l}\text { Porphyrotopic single or multiple } \\
\text { crystals, some replacing several } \\
\text { protonodules }\end{array}$ & $\begin{array}{l}\text { Isolated crystals, rims and } \\
\text { replacement of gypsum by polymodal } \\
\text { planar-s rhombs with grain-size av. } \\
0.11 \mathrm{~mm} \text {, cloudy cores }\end{array}$ \\
\hline $\begin{array}{l}\text { Prismatic } \\
\text { gypsum }\end{array}$ & $\begin{array}{l}\text { Dispersed single and radiating } \\
\text { aggregates originating from } \\
\text { anhydrite nodule margin }\end{array}$ & $\begin{array}{l}\text { Overprinting nodular or chicken-wire } \\
\text { anhydrite }\end{array}$ & 5 & As for nodular anhydrite & $\begin{array}{l}\text { Well terminated prismatic } \\
\text { crystals up to } 20 \times 10 \mathrm{~mm}\end{array}$ & None \\
\hline $\begin{array}{l}\text { Irregular nodules } \\
\text { anhydrite and } \\
\text { gypsum }\end{array}$ & $\begin{array}{l}\text { Dispersed elongate aggregates } \\
\text { with intricate, irregular margins }\end{array}$ & $\begin{array}{l}\text { Dolostone; may pass down into thinly } \\
\text { laminated evaporite - dolostone couplets }\end{array}$ & 5 & $\begin{array}{l}\text { Aphanitic aggregates with some } \\
\text { coarser elongate crystals }\end{array}$ & Porphyrotopic & $\begin{array}{l}\text { Narrow margin polymodal planar-s } \\
\text { rhombs, scattered unimodal planar-e } \\
\text { to abundant close-packed aggregates } \\
\text { of polymodal planar-s }\end{array}$ \\
\hline $\begin{array}{l}\text { Mosaic } \\
\text { anhydrite }\end{array}$ & $\begin{array}{l}\text { High proportion (up to } 85 \% \text { ) of } \\
\text { generally small }(<1 \mathrm{~cm}) \text { nodules } \\
\text { dispersed through matrix. }\end{array}$ & $\begin{array}{l}\text { Dolostone and siltstone. Typically grades } \\
\text { into nodular or chicken-wire forms. }\end{array}$ & 5 & As for protonodular anhydrite & Not seen & Not seen \\
\hline $\begin{array}{l}\text { Nodules } \\
\text { anhydrite }\end{array}$ & $\begin{array}{l}\text { Round to elongate or angular and } \\
\text { irregular nodules and nodular } \\
\text { masses } 1 \text { to } 15 \mathrm{~cm} \text { across; margins } \\
\text { sharp and smooth or cauliform; } \\
\text { some narrow enclaves of siltstone } \\
\text { or dolostone. Sinuous trains } \\
\text { forming enterolithic veins }\end{array}$ & $\begin{array}{l}\text { Common as isolated single and clustered } \\
\text { masses in typically laminated siltstone and } \\
\text { dolostone; lamination deformed above and } \\
\text { below mass. Also occurs with chicken-wire } \\
\text { and laminated anhydrite forms }\end{array}$ & $1,2,5$ & $\begin{array}{l}\text { Aphanitic, roughly circular to } \\
\text { rhombohedral 'cores'; surrounded by } \\
\text { parallel-aligned and sheaf-like } \\
\text { aggregates of ragged laths, becoming } \\
\text { decussate locally; patchily overgrown } \\
\text { by stubby subhedral granular grains. } \\
\text { Grains } 0.0018 \text { to } 0.21 \text { mm. Aligned } \\
\text { texture typical at nodule margin }\end{array}$ & $\begin{array}{l}\text { Nodules rimmed with } \\
\text { porphyrotopic gypsum average } \\
0.6 \mathrm{~mm} \text {; grain boundaries } \\
\text { irregular, extinction undulose, } \\
\text { and contain anhydrite inclusions }\end{array}$ & $\begin{array}{l}\text { Margins rimmed with polymodal, } \\
\text { planar-s; dispersed unimodal planar- } \\
\text { e crystals within nodule to increasing } \\
\text { overprint with polymodal planar-s } \\
\text { aggregates; average grain size } 0.1 \\
\mathrm{~mm} \text {. }\end{array}$ \\
\hline $\begin{array}{l}\text { Chicken-wire } \\
\text { anhydrite }\end{array}$ & $\begin{array}{l}\text { Mass of coalesced } \\
\text { microcrystalline anhydrite } \\
\text { nodules, separated by mm wide } \\
\text { discontinuous relicts of siltstone } \\
\text { or dolostone between nodules. } \\
\text { Nodules are irregular and typically } \\
\text { flattened, some elongated } \\
\text { vertically. }\end{array}$ & $\begin{array}{l}\text { Minor included siltstone or dolostone; } \\
\text { associated with nodular and laminated } \\
\text { forms. }\end{array}$ & 2,5 & $\begin{array}{l}\text { Aphanitic 'cores' and parallel-aligned, } \\
\text { elongate crystals } 0.0018 \text { to } 0.21 \mathrm{~mm} \\
\text { adjacent to nodule margin and in } \\
\text { smaller nodules. Replaced in some } \\
\text { samples by granoblastic anhydrite } \\
\text { which increases from }<0.1 \mathrm{~mm} \text { near } \\
\text { margin to } 0.36 \text { to } 0.49 \mathrm{~mm} \text { in centre. }\end{array}$ & Not seen & $\begin{array}{l}\text { Not commonly present; sporadic } \\
\text { dispersed unimodal, planar-s rhombs } \\
\text { with cloudy cores and clear rims (av. } \\
0.11 \mathrm{~mm} \text { ); sporadic dispersed } \\
\text { unimodal planar-e rhombs. }\end{array}$ \\
\hline Anhydrite-rock & Homogeneous microcrystalline & Always in association with other facies. & 2,4 & Nematoblastic to granoblastic; parallel & Replacement by veins of & Sporadic dispersed unimodal planar-s \\
\hline
\end{tabular}

This article is protected by copyright. All rights reserved 


\begin{tabular}{|c|c|c|c|c|c|c|}
\hline & $\begin{array}{l}\text { anhydrite with lamination defined } \\
\text { by discontinuous trails and } \\
\text { enclaves of siltstone }\end{array}$ & $\begin{array}{l}\text { Sharp contacts with chicken-wire or nodular } \\
\text { forms }\end{array}$ & & $\begin{array}{l}\text { aligned subsequent to elongate and } \\
\text { equant anhedral crystals with average } \\
\text { grain size } 0.2 \mathrm{~mm}\end{array}$ & $\begin{array}{l}\text { prismatic gypsum with } \\
\text { abundant tiny anhydrite } \\
\text { inclusions }\end{array}$ & $\begin{array}{l}\text { to planar-e rhombs, but when } \\
\text { granoblastic texture fully developed } \\
\text { dolomite is generally absent. }\end{array}$ \\
\hline $\begin{array}{l}\text { Laminated } \\
\text { anhydrite }\end{array}$ & Mm-scale laminae with anhydrite & Interlaminated with siltstone or dolomicrite & 4 & $\begin{array}{l}\text { Aphanitic anhydrite as lenticular and } \\
\text { prismatic pseudomorphs after } \\
\text { gypsum; or anhedral granular } \\
\text { anhydrite }\end{array}$ & Not seen & Not seen \\
\hline $\begin{array}{l}\text { Veins anhydrite/ } \\
\text { gypsum }\end{array}$ & $\begin{array}{l}\text { Abundant narrow }(<5 \mathrm{~mm}) \text {, } \\
\text { continuous or discontinuous, } \\
\text { typically subhorizontal veins of } \\
\text { gypsum or anhydrite; thicker } \\
\text { veins of satin spar. Small, irregular } \\
\text { discontinuous veins link evaporite } \\
\text { masses }\end{array}$ & $\begin{array}{l}\text { Veins cut all facies and are typically } \\
\text { characteristic of exposed strata. Gypsum } \\
\text { veins most abundant where gypsum is } \\
\text { dominant evaporite form particularly with } \\
\text { nodular gypsum. Anhydrite veins present in } \\
\text { lower parts of boreholes associated with } \\
\text { nodular anhydrite masses. }\end{array}$ & $\begin{array}{l}1,2,3 \\
4,5\end{array}$ & $\begin{array}{l}\text { Typically discontinuous fracture fills } \\
\text { with anhedral granular ( } 0.023 \text { to } 0.75 \\
\mathrm{~mm} \text { ) anhydrite within siltstone and } \\
\text { dolostone; also cutting nodular } \\
\text { fibroradiate masses }\end{array}$ & $\begin{array}{l}\text { 1. Granular aggregates (average } \\
0.4 \mathrm{~mm} \text { ) with anhydrite } \\
\text { inclusions. } 2 \text {. Stubby anhedral } \\
\text { crystals without anhydrite } \\
\text { inclusions. } 3 \text {. Satin spar, coarse } \\
\text { elongate laths, inclusion free, } \\
\text { commonly grown from each } \\
\text { side of vein. }\end{array}$ & $\begin{array}{l}\text { Planar-s dolomite overgrowths to } \\
\text { gypsum vein type } 1\end{array}$ \\
\hline Cements & $\begin{array}{l}\text { Gypsum or anhydrite (depth } \\
\text { dependent) }\end{array}$ & $\begin{array}{l}\text { Fine or very fine-grained sandstone; rarely } \\
\text { dolostone and siltstone. }\end{array}$ & & Poikilotopic crystals up to $1.5 \mathrm{~mm}$ & $\begin{array}{l}\text { Poikilotopic crystals up to } 1 \\
\mathrm{~mm} \text {. }\end{array}$ & Not seen \\
\hline
\end{tabular}

This article is protected by copyright. All rights reserved 
Table 2. Summary of the diagenesis of the evaporite rocks in the Ballagan Formation. References cited support the interpretation except for 8 and 10 which are specific to these rocks.

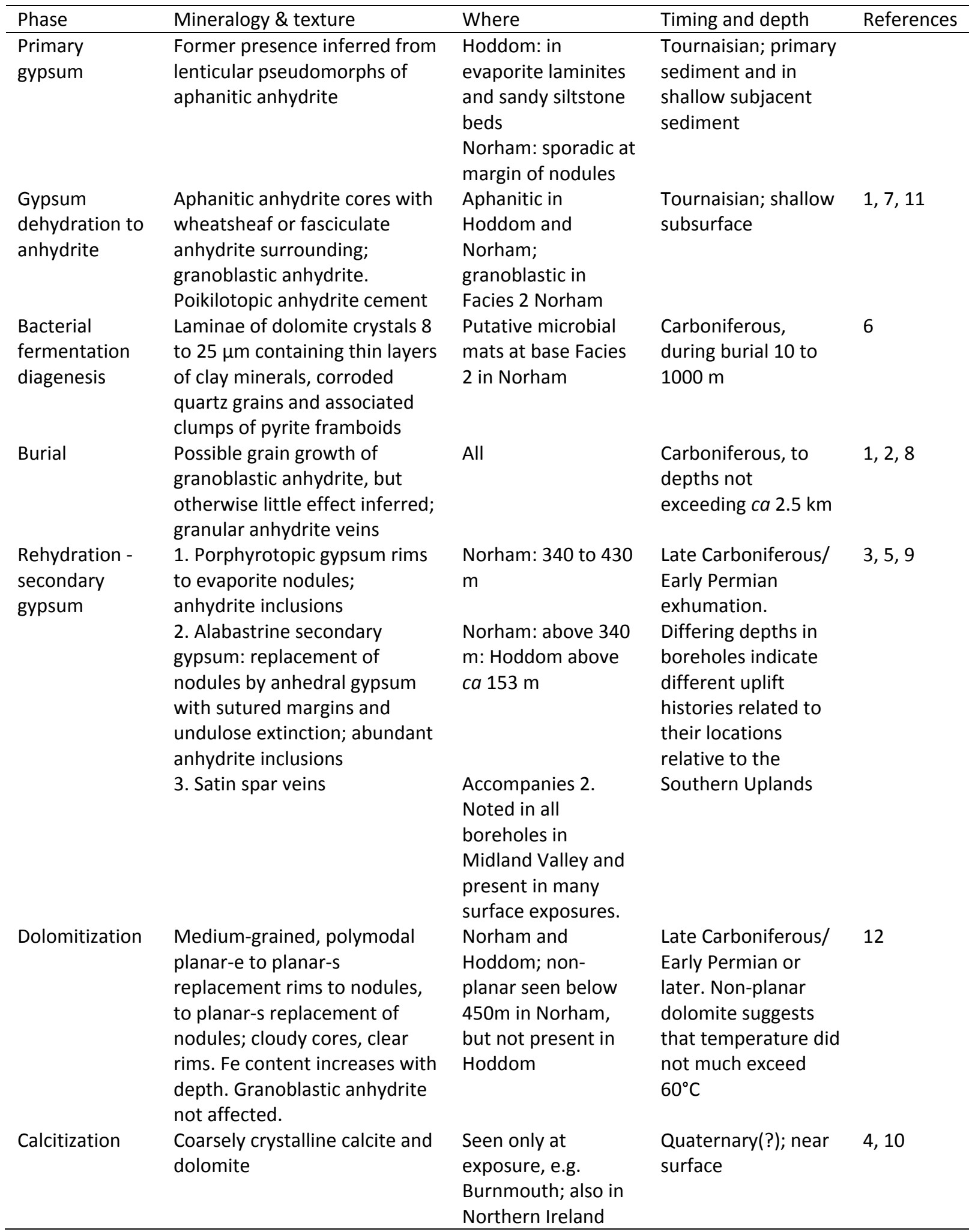

1 Aleali et al., 2013; 2 Armstrong \& Purnell, 1993; 3 Corfield et al., 1996; 4 Griffith \& Wilson, 1982; 5 Holliday, 1970; 6 Irwin, 1980; 7 Kasprzyk \& Orti, 1998; 8 Kearsey et al., 2016; 9 Ogniben, 1957; 10 Scott, 1986; 11 Shearman \& Fuller, 1969; 12 Warren, 2000

This article is protected by copyright. All rights reserved 


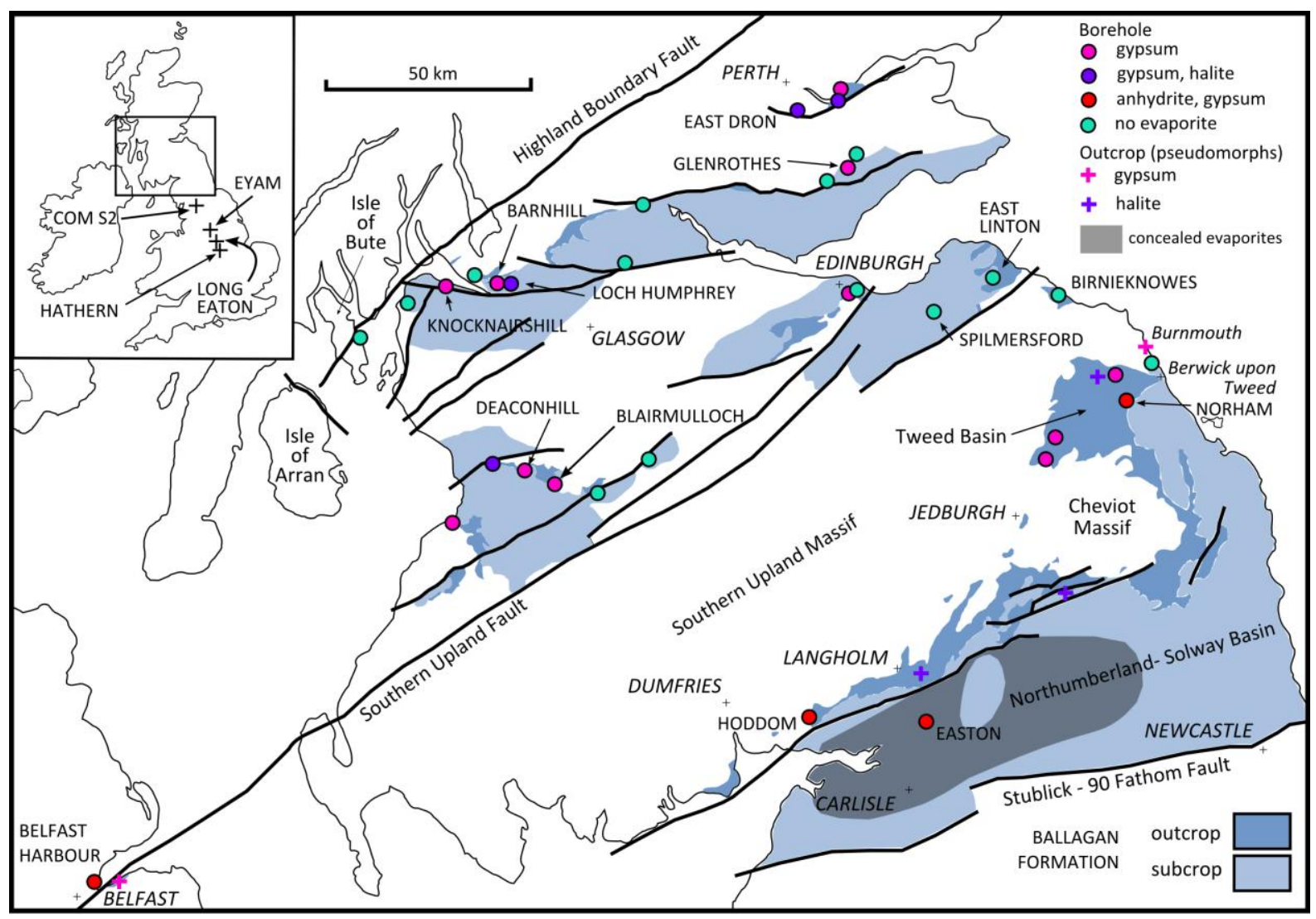

This article is protected by copyright. All rights reserved 

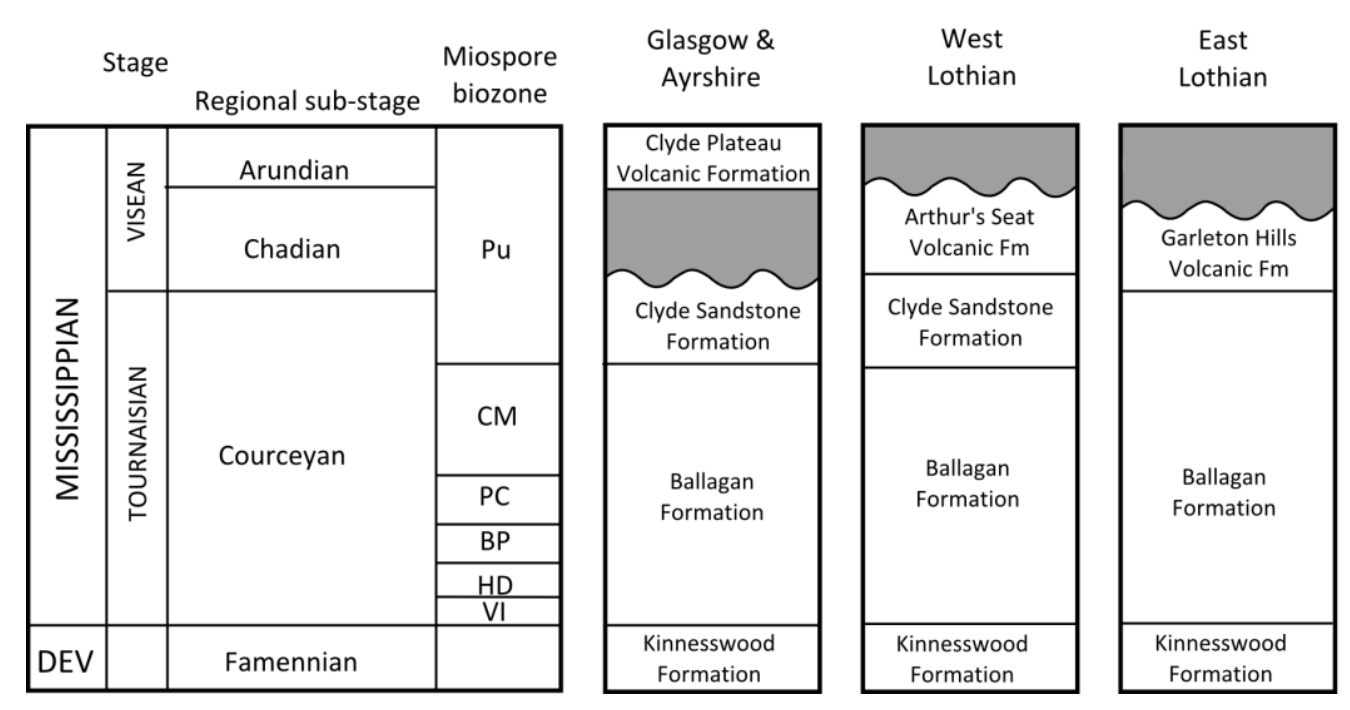

Northumberland

-Solway

Basin

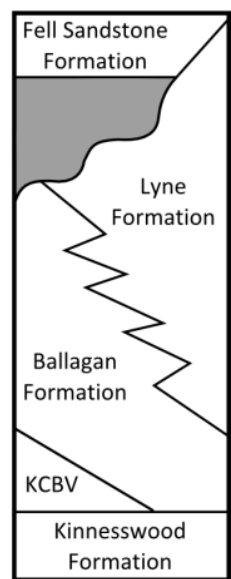




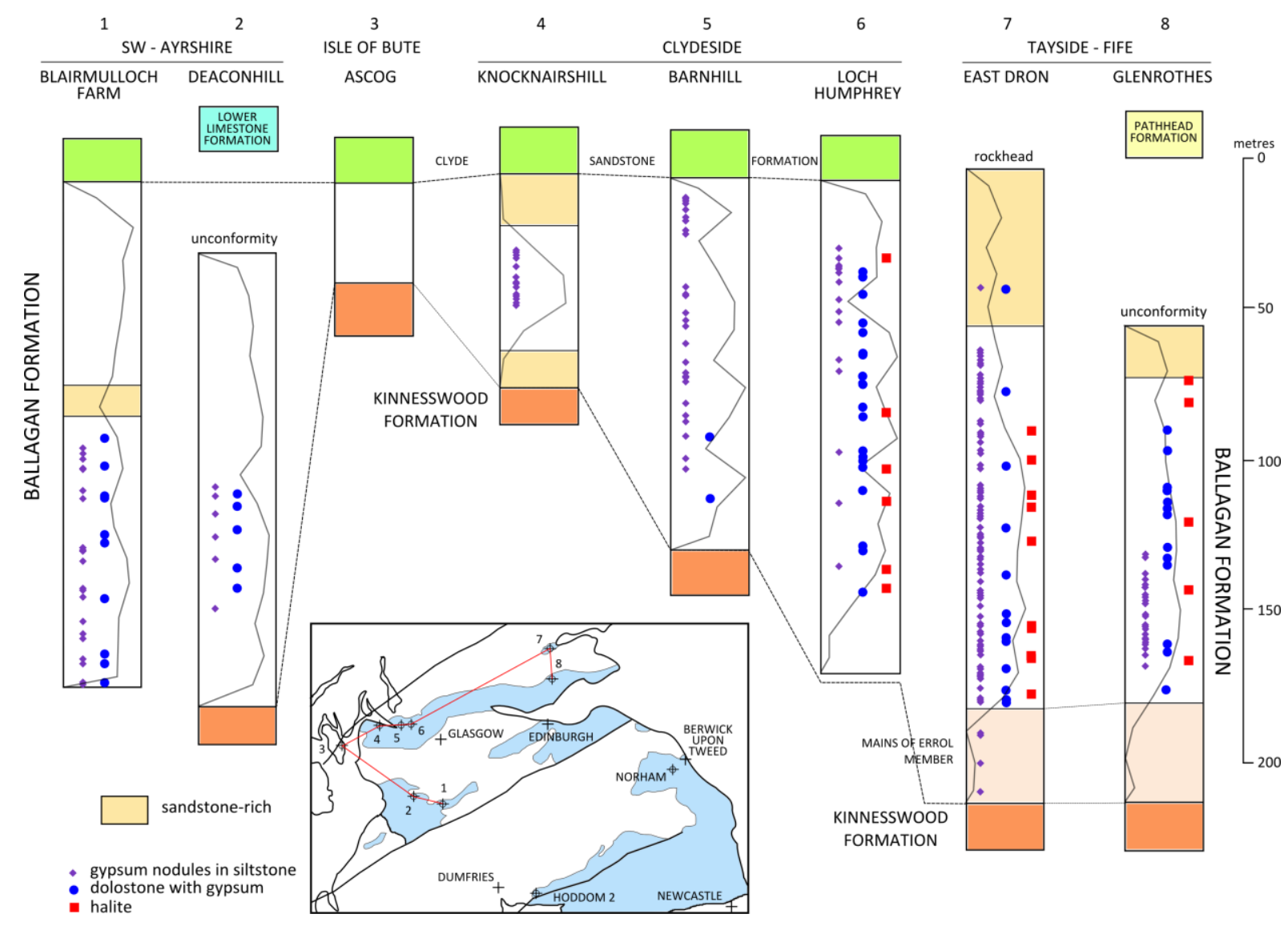



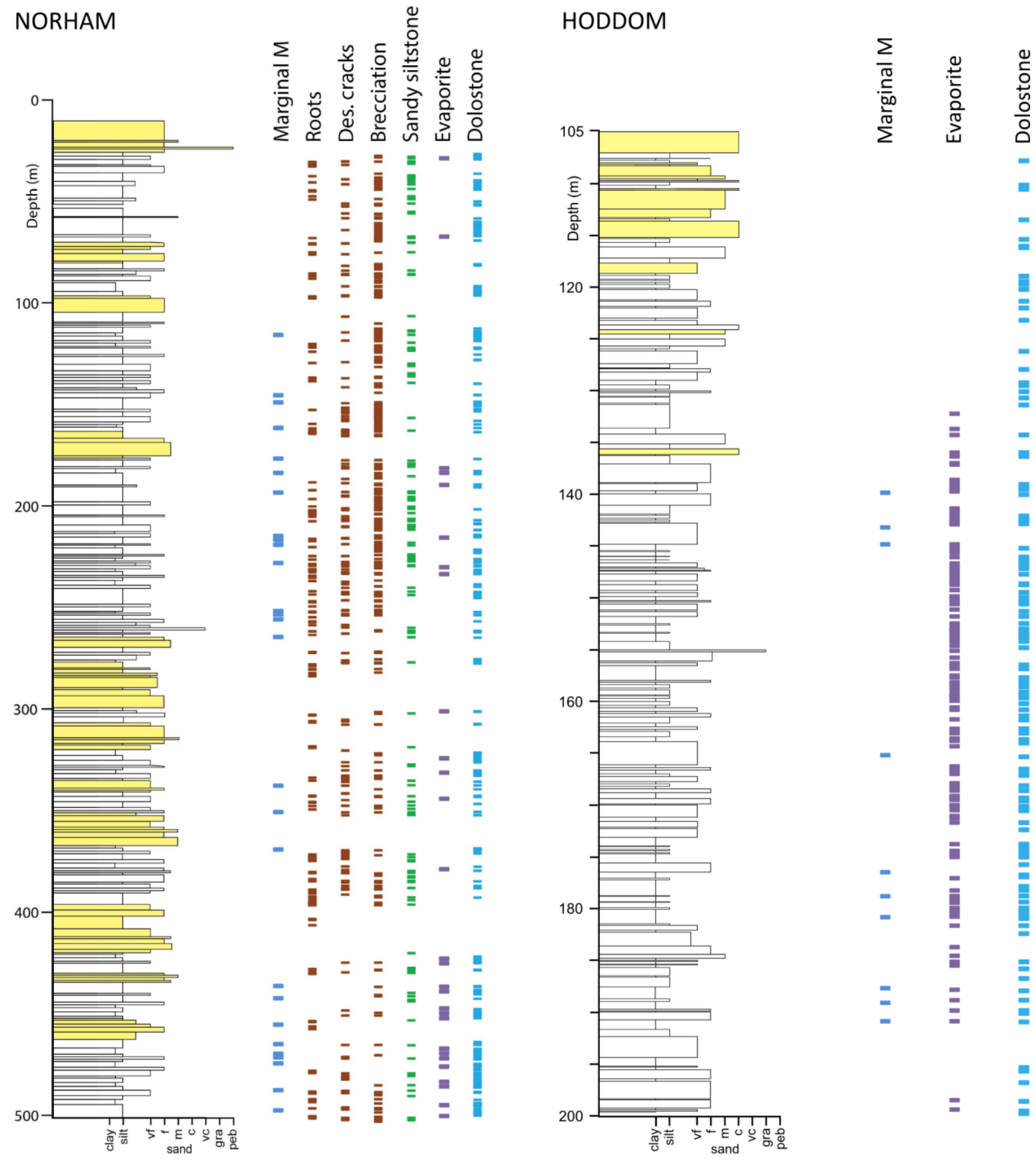

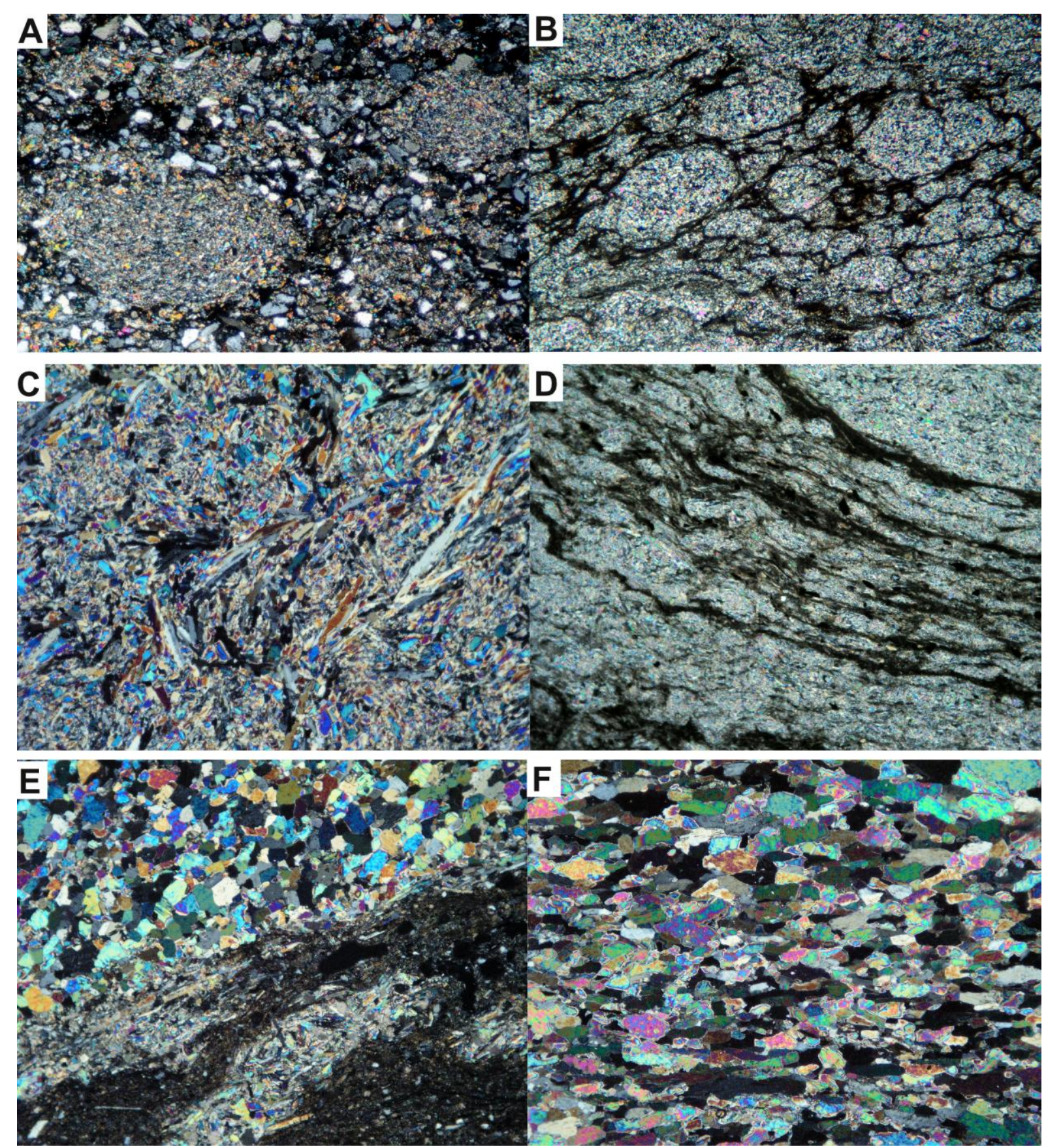

This article is protected by copyright. All rights reserved 


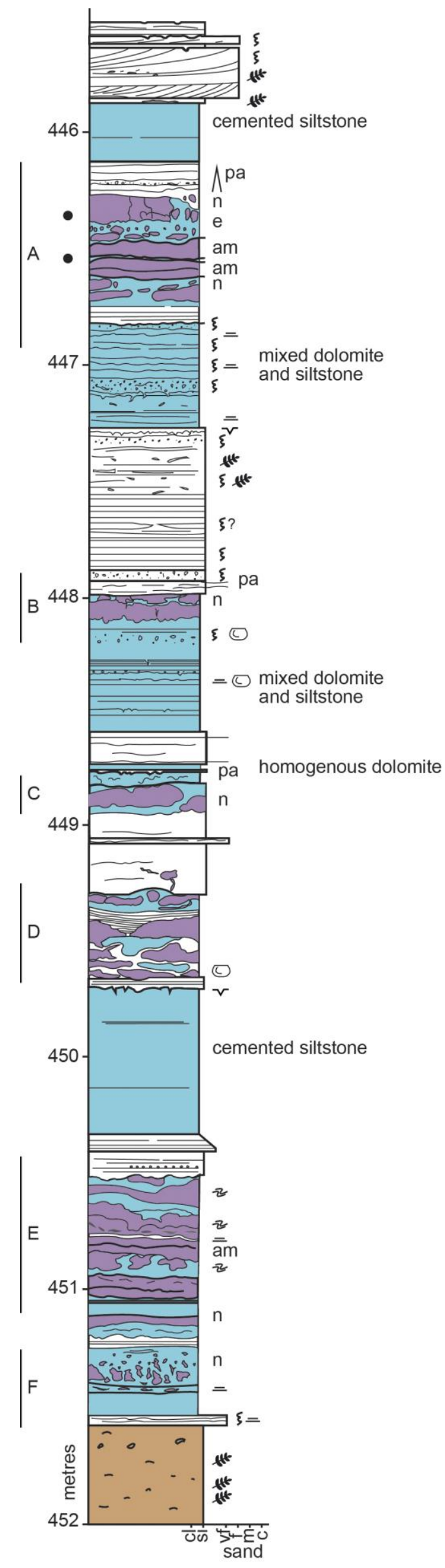

This article is protected by copyright. All rights reserved 


$\begin{array}{lcll}\begin{array}{l}\text { evaporite beds, } \\ \text { gypsum or anhydrite }\end{array} & \checkmark & \text { brecciation } \\ \text { dolostones } & \text { ef } & \text { plant fragments } \\ & \xi & \text { bioturbation } \\ \text { sandy siltstones } & (4) & \text { ostracods } \\ \text { parallel laminated } & \text { am } & \text { microbial mat } \\ \text { bedding } & \mathrm{n} & \text { nodule } \\ \text { convoluted bedding } & \text { pa } & \text { anhydrite protonodules }\end{array}$

This article is protected by copyright. All rights reserved 


\section{A}
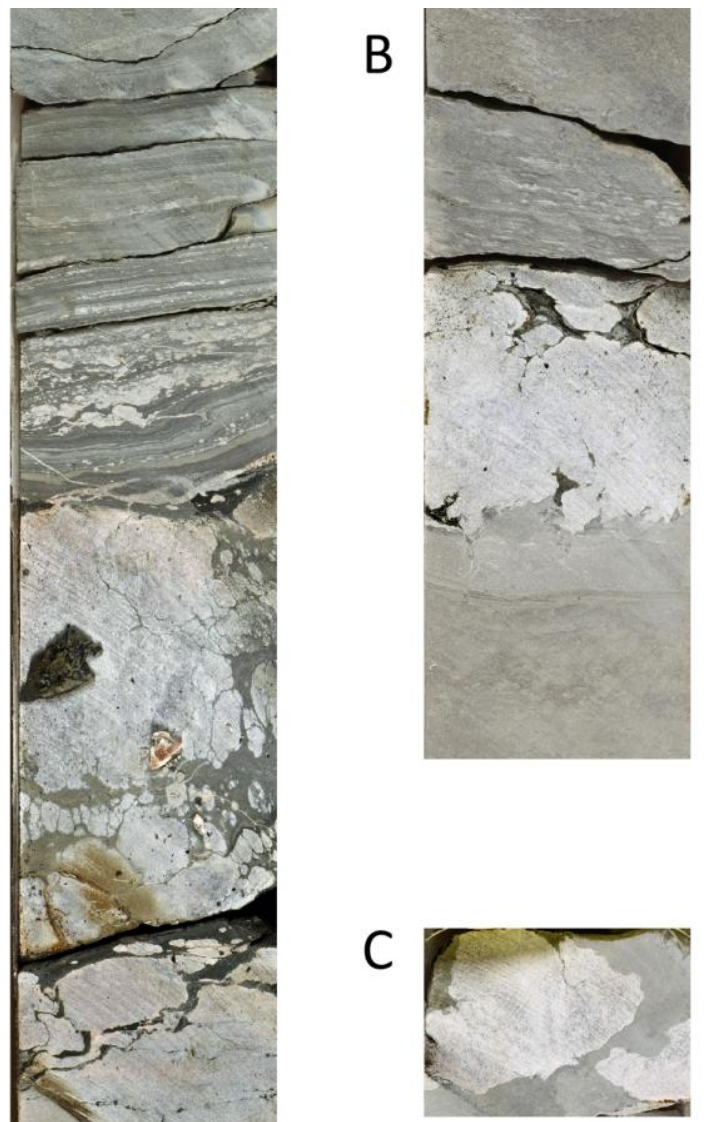

D

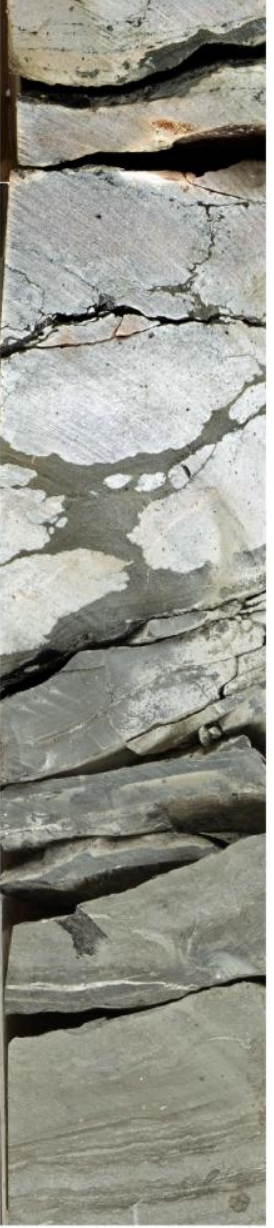

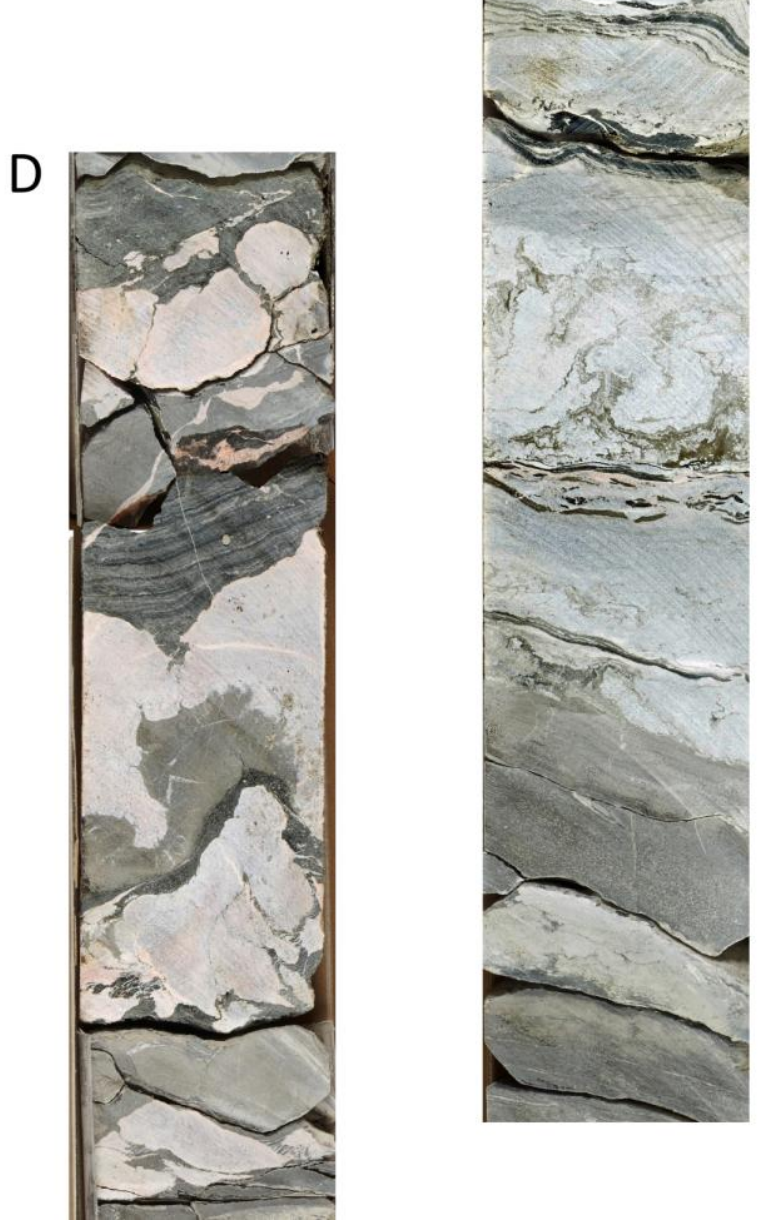

E

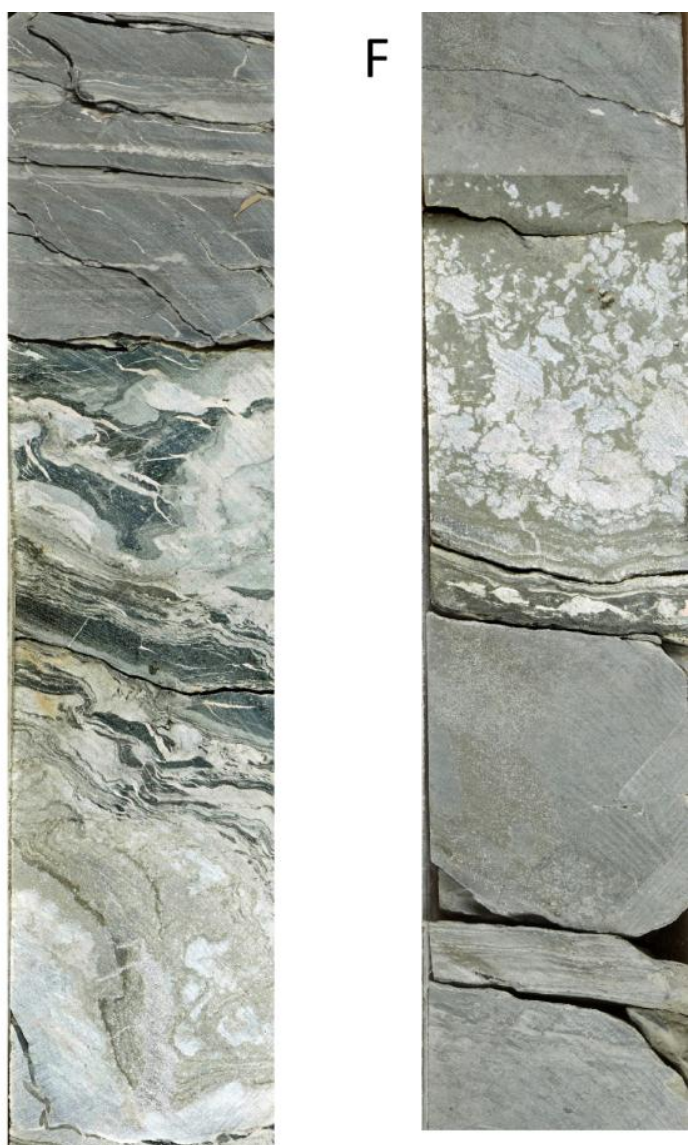

This article is protected by copyright. All rights reserved 

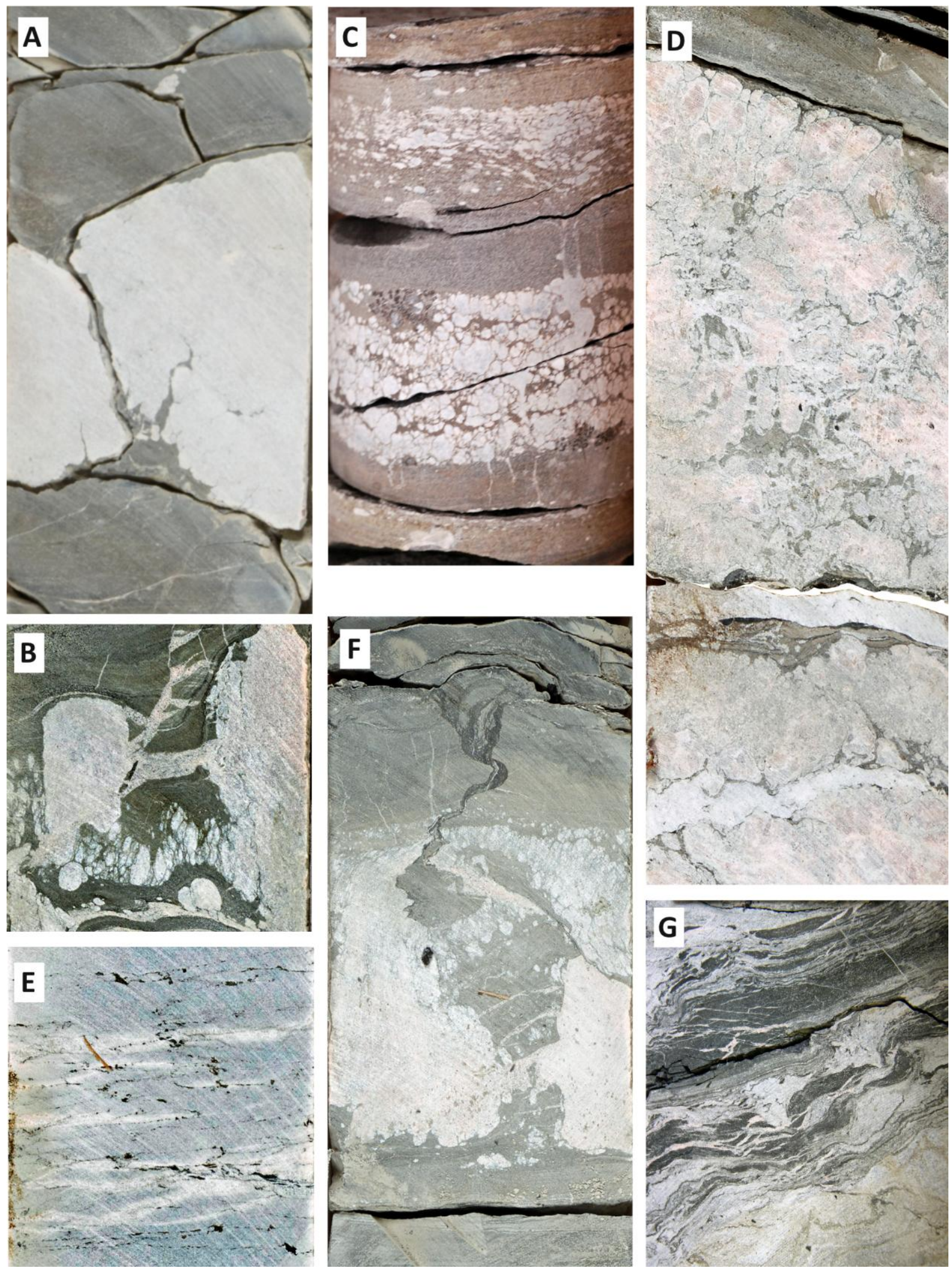

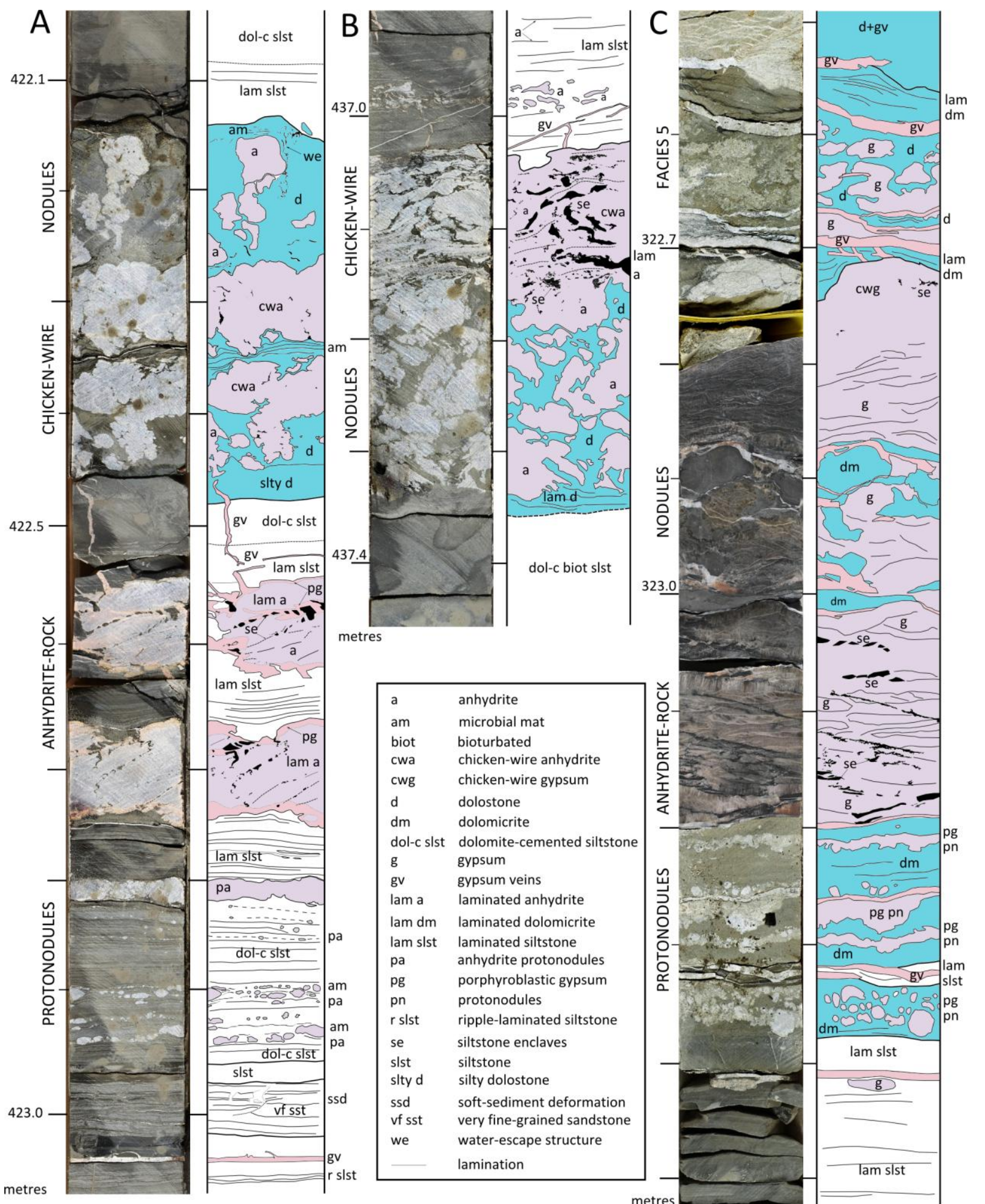

\begin{tabular}{ll|}
\hline a & anhydrite \\
am & microbial mat \\
biot & bioturbated \\
cwa & chicken-wire anhydrite \\
cwg & chicken-wire gypsum \\
d & dolostone \\
dm & dolomicrite \\
dol-c slst & dolomite-cemented siltstone \\
g & gypsum \\
gv & gypsum veins \\
lam a & laminated anhydrite \\
lam dm & laminated dolomicrite \\
lam slst & laminated siltstone \\
pa & anhydrite protonodules \\
pg & porphyroblastic gypsum \\
pn & protonodules \\
r slst & ripple-laminated siltstone \\
se & siltstone enclaves \\
slst & siltstone \\
slty d & silty dolostone \\
ssd & soft-sediment deformation \\
vf sst & very fine-grained sandstone \\
we & water-escape structure \\
& lamination \\
\hline &
\end{tabular}

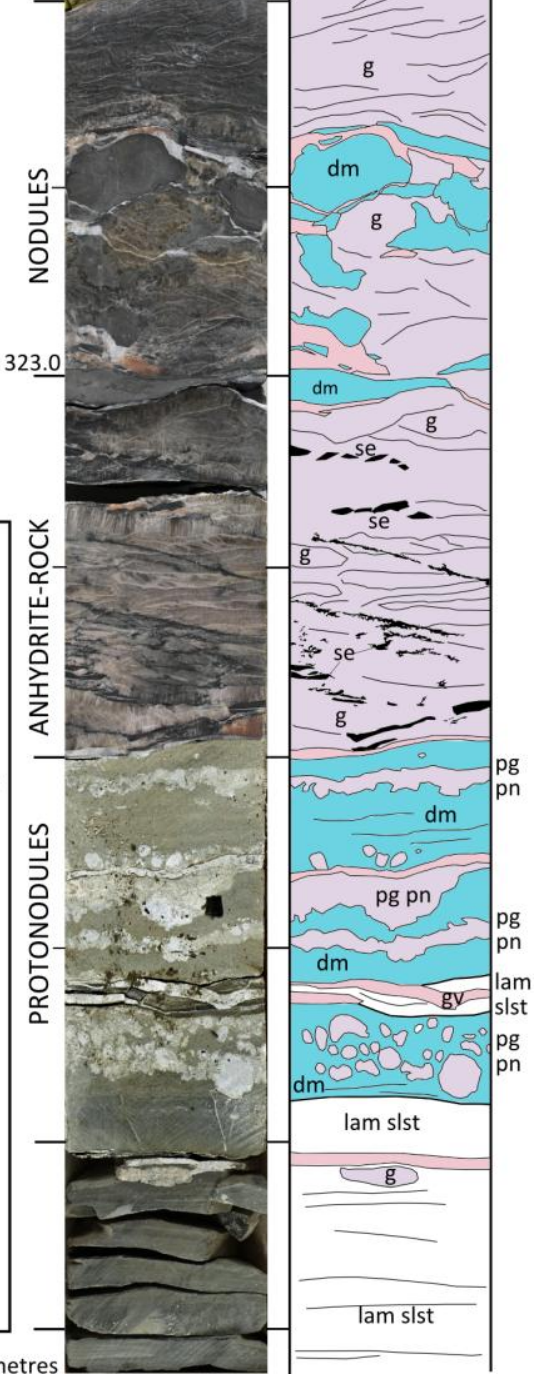

This article is protected by copyright. All rights reserved 


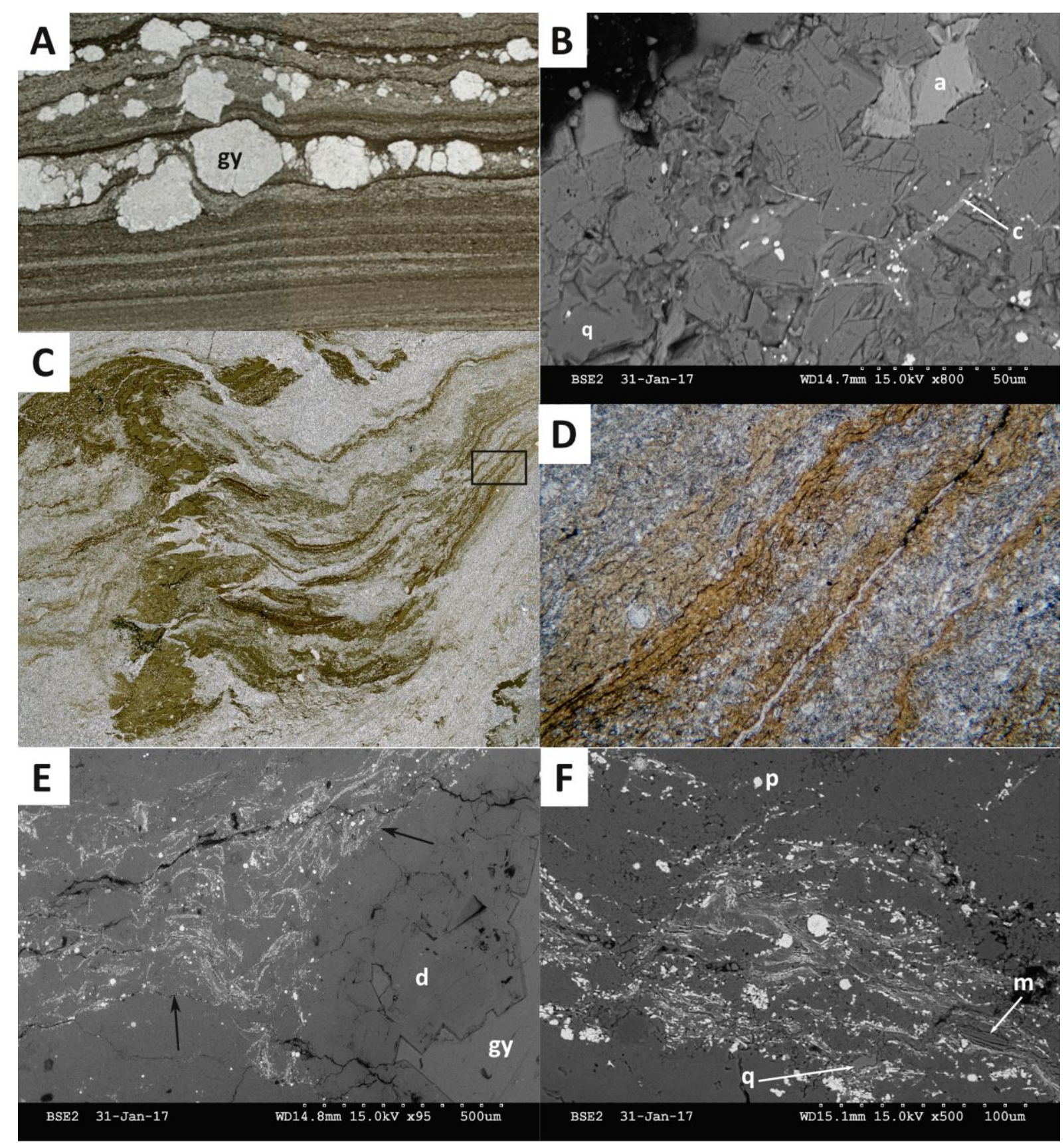

This article is protected by copyright. All rights reserved 


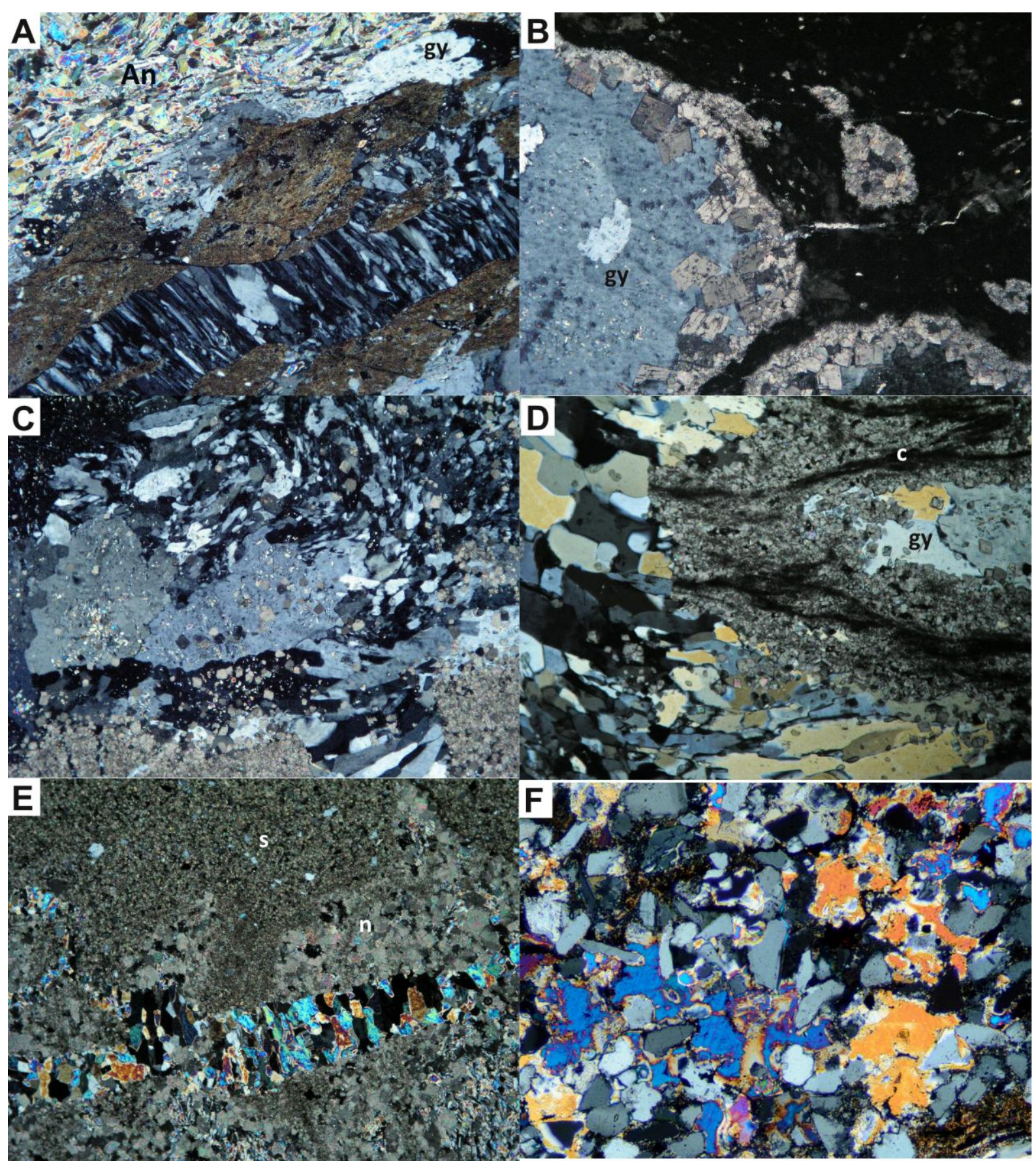

This article is protected by copyright. All rights reserved 


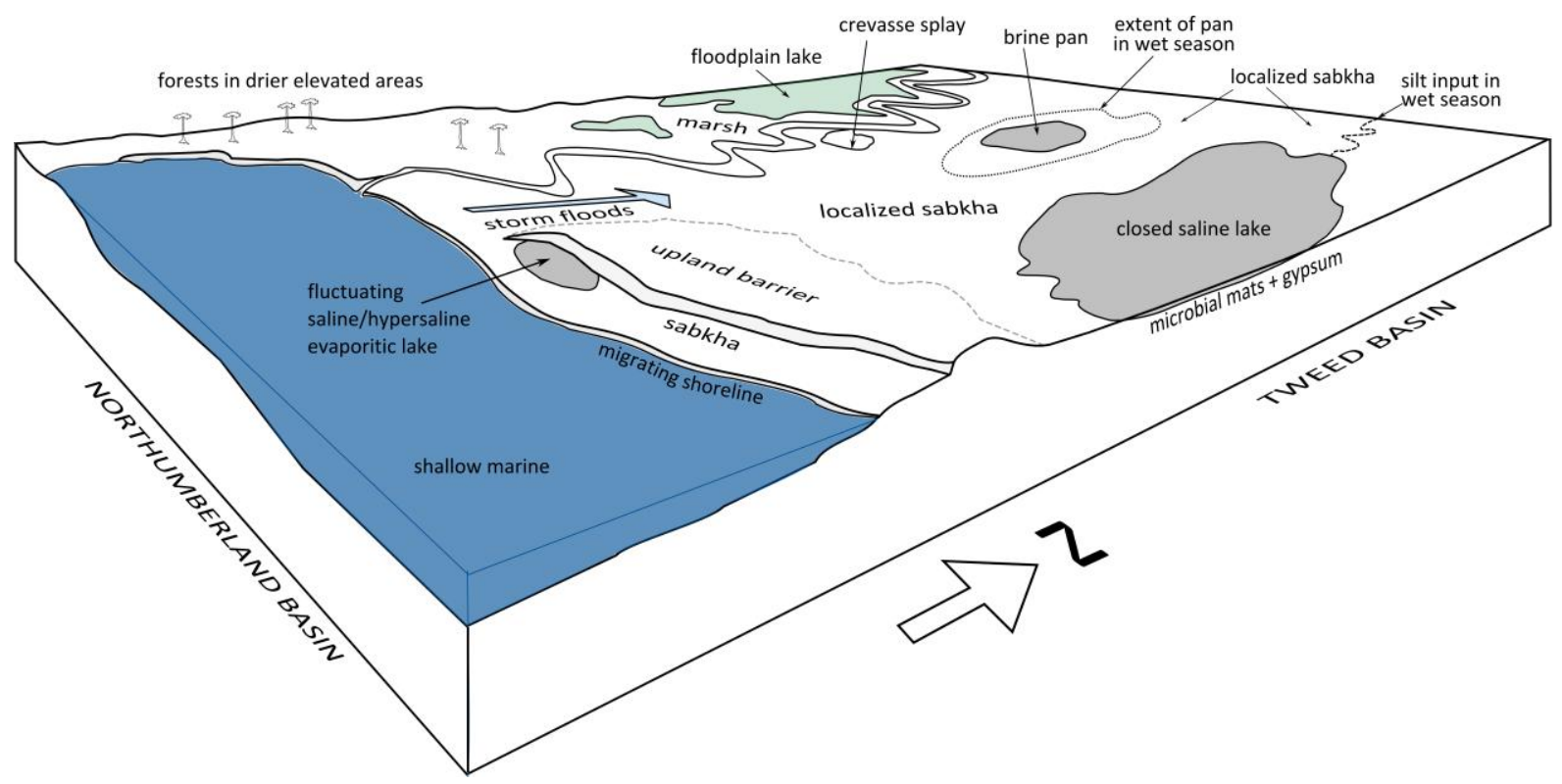

This article is protected by copyright. All rights reserved 